\title{
Effects of low concentration of proanthocyanidins and oxidation conditions on myofibrillar protein in chicken breast muscle
}

\author{
Jingyuan Li ( $\sim 1310757678 @ q q . c o m)$ \\ Qingdao Agricultural University \\ Zhuoqi Zheng \\ Qingdao Agricultural University \\ Songyan Li \\ Qingdao Agricultural University
}

\section{Research Article}

Keywords: Proanthocyanidins, Gel, NaNO2, Characterize, HPLC

Posted Date: December 27th, 2021

DOI: https://doi.org/10.21203/rs.3.rs-1050184/v1

License: (c) (i) This work is licensed under a Creative Commons Attribution 4.0 International License.

Read Full License 


\section{Abstract}

In this study, the effect of low concentration of proanthocyanidins (extracted from grape seeds) on the gel properties of chicken breast myofibrillar protein was studied. The addition of proanthocyanidins could strengthen the spatial structure of myofibrillar proteins and slow down the gel oxidation. The threshold value of the addition amount of proanthocyanidins refers to the threshold value of NaNO2, a commonly used food additive in meat products, closer to the actual production and application. In the threshold range, low concentration of proanthocyanidins had more stable water retention and slower structural decay. High concentration of proanthocyanidins' gel (PG) had better stability in the first ten days, but a rapid decline occurred after 10 days. Raman microscope showed that the gel formed after adding proanthocyanidins had more compact spatial structure and smaller pore size, which was more conducive to maintaining water content. In this experiment, when the amount of proanthocyanidins exceeded the national standard threshold, the spatial structure of the gel was destroyed, and the data were disordered. Proanthocyanidins extracted from grape seeds (PFGS) could be appropriately added within the national standard threshold, which was beneficial to the stability, oxidation resistance and texture of the gel. Therefore, improving the stability of protein gel systems was important for the design and development of novel food products.

\section{Introduction}

CMPG was a method of extracting protein from meat products and conducting specialized research on protein properties. By extracting the protein, other ingredients in meat products can be prevented from having uncertain effects on the research protein. The formation of CMPG was based on the salting-out effect of protein, which causes the protein to agglomerate and precipitate out of the solution ${ }^{1}$. The stability of the gel affects the stability of the protein to a certain extent. Thermal processing was one of the common methods for producing CMPG. During the heating process of the protein, the protein backbone was broken at low temperature and the hydrophobic group was exposed. As the temperature rises, the protein aggregates, the a-helical structure unfolds, and it gradually transforms into a $\beta$-sheet structure ${ }^{2}$. The gelation of proteins comes from the cross-linking between proteins through covalent and non-covalent bonds, including ionic bonds, hydrogen bonds, hydrophobic interactions, disulfide bonds and other covalent bonds. Play a decisive role in the production of gel. Therefore, to avoid the gel degradation, this study adopted a two-stage water bath heating (TS-WB) method $\left(30^{\circ} \mathrm{C}\right.$ heating at a speed of $1^{\circ} \mathrm{C} / \mathrm{min}$ for $50 \mathrm{~min}$ to $80^{\circ} \mathrm{C}$ and $80^{\circ} \mathrm{C}$ heating for $20 \mathrm{~min}$ ) to prepare CMPG.

Proanthocyanidins (Pas) were oligomeric or high polyphenolic substances with flavan-3-ols as the basic structural unit, which could produce anthocyanidins under thermal acid treatment. Proanthocyanidins were widely distributed in the leaves, seeds and peels of plants, and they were the second largest type of dietary polyphenols in the plant kingdom. Pas could play an effective role in anti-oxidation, weight loss and lipid-lowering, neuroprotection, anti-ovarian cancer, analgesia, anti-inflammatory, antibacterial and inhibition of melanin production ${ }^{3,4}$. At the same time, its food safety has been preliminarily proved through animal models. Pas were rich in hydrophobic aromatic rings and hydroxyl groups, and might 
interact with biomolecules, especially proteins, through hydrogen bonds and hydrophobic interactions. Since Pas were polymers, they have a stronger effect on proteins than single-molecule flavonoids ${ }^{5}$. Hydrogen bond interaction and hydrophobic interaction make Pas better bind to proteins. Pas-protein complexes form hydrogen bonds between phenol residues and polar groups in the protein, and the phenol residues and the weak in the protein Polar groups such as the hydrophobic interaction between proline residues. Based on the relative concentration of the two ligands, this phenomenon could be regarded as the polar and soluble proteins being wrapped by Pas molecules or forming a molecular network by connecting multifunctional Pas molecules to multiple proteins at the same time. Therefore, Pas often causes protein precipitation or enzyme activity inhibition. This property of Pas wasusually called astringency and has nutritional significance. Pas wasa part of plant extracts, and phenolic substances have important value in inhibiting the formation of rancid odors in meat products by acting as free radical scavengers as hydrogen atoms or electron donors. However, adding high levels of antioxidants wasdetrimental to the food industry, because high concentrations of phenolic compounds might change the food matrix, including color and touch. Oxidation wasa natural process that occurs during meat processing and storage. However, no studies have been published to evaluate the effects of appropriate concentrations of proanthocyanidin compounds on the oxidative stability and gelling properties of proteins.

In recent years, the methods of gel research have emerged endlessly, such as low-field nuclear magnetism, rheology, texture, infrared spectroscopy, Raman spectroscopy, circular dichrograph, laser particle size analyzer, scanning electron microscope, transmission electron microscope, laser confocal microscope, and differential. Scanning calorimeters, etc., can systematically characterize the water content, water retention, texture, microstructure, molecular bond vibration, etc. of the gel, and fully and systematically express the characteristics of the gel. The Silicon pressure resistance sensor used in this experiment is a volume detection method for irregular solids through electrical signals, which is more accurate and has less errors than other methods.

\section{Results And Discussion}

\subsection{Proanthocyanidins preparation}

The catechin standard curve was taken as abscissa by the concentration of catechin standard solution, and the absorbance was taken as ordinate. The Fig. 1 show the results for the regression equation : $Y=0.001191 X+0.00123, R^{2}=0.99988$. The final extraction rate was $5.29 \%$ and the relative deviation was $0.638 \%$.

The red curve was the HPLC-FLD chromatogram containing Catechin/epicatechin, Procyanidin dimer and Procyanidin tetramer, black curve was the HPLC-FLD chromatogram of redissolved proanthocyanidins after lyophilisation in Fig.2. From chromatograms and references, the main components of proanthocyanidins extracted by this method were Catechin/epicatechin, Procyanidin dimer and Procyanidin tetramer, and their ratio was 5:31:4. 


\subsection{Protein purity and particle size}

The Biuret Method was used to detect the current purified protein, and the measured purity result was $90.08 \pm 2.27 \%$, which was greater than or equal to the purity of some proteins studied ${ }^{6,7}$, so the experiment was feasible in terms of protein purity. In this experiment, the freeze-dried protein was manually ground. The reason was to prevent mechanical grinding from transforming, degrading, or even destroying the internal groups and disulfide bonds between the proteins, which made the gel structure unstable ${ }^{8}$, which could affect the experimental results. In this experiment, mortar was used for grinding, and the protein particles after grinding were tested by DLS. DLS results show that the distribution of MP was relatively wide (2296-3592 nm) and the average particle size was larger $(3007 \pm 18 \mathrm{~nm})$, reflecting the uneven dispersion of MPs (Fig. 3).

\subsection{Texture characteristics}

Texture was closely related to sensory characteristics, physicochemical properties, and processing characteristics of gelatinous products. Hardness, chewiness and springiness were the important indicators for texture characteristics, because they directly affect the quality of gelatinous products.

In the Fig.4, category 0 was the blank contrast, and category $1-4$ was $0.05,0.10,0.15,0.20 \mathrm{~g} / \mathrm{kg} \mathrm{NaNO}{ }_{2}$, abbreviated as C1, C2, C3, C4, respectively. Category 5-9 was $0.05,0.10,0.15,0.20,0.25 \mathrm{~g} / \mathrm{kg}$ PFGS, referred to as $\mathrm{C} 5, \mathrm{C} 6, \mathrm{C} 7, \mathrm{C} 8, \mathrm{C}$, respectively. a was the data map of springiness, b was the data map of chewiness, $\mathrm{c}$ was the data map of hardness

It could be seen from Fig.4-a that springiness of the gel increased with the increase of $\mathrm{NaNO}_{2}$ and PFGS addition, but the springiness of the $0.20 \mathrm{~g} / \mathrm{kg}$ proanthocyanidins group (PG) was only $8.3587 \% \pm 0.657$ $\%$ higher than that of the $\mathrm{NaNO}_{2}$ group. In addition, Fig.18 showed that through the sensory evaluation of 300 random people, $96.832 \%$ believed that elasticity did not change. It could be seen from the Fig.4-a that after 20 days of storage at $4{ }^{\circ} \mathrm{C}$, the springiness decay rate of the original anthocyanin group was lower than that of the $\mathrm{NaNO}_{2}$ group, and the decay rate was $13.574 \%$ lower than that of the $\mathrm{NaNO}_{2}$ group. It was believed that the decrease of springiness was related to the loss of free water and the destruction of disulfide bonds in the gel during 20 days. It could be seen from Fig. 8 that the volume measured by SPRS also showed that the gel had a certain degree of shrinkage and collapse. However, from the data, the gel collapse rate of the PG was slower than that of the blank contrast group. This may be due to the polymerization of C-ring in PFGS with $\mathrm{C}-\mathrm{C}$ and $\mathrm{C}-\mathrm{N}$ bonds in gel particles during the heating process of gel formation, which strengthens the interaction between bonds in gel.

The chewing force data in Fig.4-b showed that the chewing force of the gel in the $\mathrm{NaNO}_{2}$ group increased slowly with the increase of $\mathrm{NaNO}_{2}$ content. The masticatory force of the $\mathrm{PG}$ at $0.05 \mathrm{~g} / \mathrm{kg}$ was lower than that of the blank contrast gel. Considering that the adhesiveness and cohesion of the gel formed were insufficient when the concentration of PFGS was too low, and the influence on the disulfide bond and the amide bond was unstable, which led to the lower masticatory force at $0.05 \mathrm{~g} / \mathrm{kg}$. However, with the 
increase of the amount of the original pigment, it could be seen that the chewing force had a very rapid growth trend. At the same time, the respondents also obviously feel that the gel chewing force of the original pigment group at $0.20 \mathrm{~g} / \mathrm{kg}$ had been greatly strengthened, and the touch was more like rubber.

With the passage of time, the decline rate of chewing force in the $\mathrm{NaNO}_{2}$ group was roughly the same and the decline was slow. The chewing force in the PG at all concentrations decreased rapidly with time. It could be seen that PFGS could play an antioxidant and stabilizing role in gel formation, but PFGS were easy to polymerize and had too many oligomeric forms, resulting in the molecular groups of PFGS and gel formation were very different. As time goes by, different molecular groups turn into new molecular forms due to oxidation, resulting in a softening of the gel layer outside the gel. When the gel of the 20-day PG was sliced, it was found that the gel surface was soft and crisp, but the central part still showed gel properties. This was consistent with the observation trend of Raman microscope. It could be seen from Fig.4-c that with the increase of the concentration of the original pigment group and the $\mathrm{NaNO}_{2}$ group, the hardness of the formed gels increased, and with the passage of time, the hardness of the gels still increased, which was directly related to the water loss of the gels. The free water content of the two groups decreased significouldtly on 20 days, and the gels showed hard and brittle properties.

In summary, it could be seen that when the original pigment was $0.25 \mathrm{~g} / \mathrm{kg}$, the gel did not form bulky elastic substances, but formed flocculent condensation substances. The substances in this state did not had gel properties, and the detection also showed data different from the gel, which was corresponding to the following infrared characterization. When the original pigment was $0.25 \mathrm{~g} / \mathrm{kg}$, the data of formed substances were disordered. At the same time, it was found that the parallelism of PG was more unstable than that of $\mathrm{NaNO}_{2}$ group in the process of texture detection. It was analyzed that during the heating process of gel formation, different proanthocyanidins oligomers or polymers were formed, and different polymers had different effects on S-S, which made the experimental stability of PG lower than that of $\mathrm{NaNO}_{2}$ group. This could be seen from the experimental error.

\subsection{FTIR analysis}

FTIR was applied to further investigate the intermolecular interactions in Protein- Proanthocyanidins matrixes. As shown in Fig. 5 the broad band centered at $3000-3600 \mathrm{~cm}^{-1}$ was assigned to $\mathrm{O}-\mathrm{H}$ and $\mathrm{N}-\mathrm{H}$ groups, implying the potential for hydrogen-bonding interactions $\square$ This means that with the addition of PFGS, $\mathrm{O}-\mathrm{H}$ and $\mathrm{N}-\mathrm{H}$ groups in the gel force increased,

Compared to blank contrast, the stretching vibrations of $\mathrm{O}-\mathrm{H}$ and $\mathrm{N}-\mathrm{H}$ groups appeared at 3000-3500 $\mathrm{cm}^{-1}$, revealed enhanced intensity profiles for $0.15 \%$ and $0.20 \%$ PFGS, which suggesting that the intensities of inter- and intra-molecular hydrogen bonds were enhanced. This was a favorable change in affecting affinities between proteins. The strong hydrogen bond potentials in the MPs surface contributed to the stability and order between proteins, and accelerated the process of rearrangement and aggregation. The change was then noticeably reflected in $0.20 \%$ PFGS which had a minimal particle size 
because of exposure of internal functional groups, or selfregulation of secondary structures within ground MPs due to that polymerization of PFGS during the formation of gel.

\subsection{LF-NMR}

LF-NMR had been widely used to evaluate the distribution and mobility of different fractions of water molecules in a gel system. According to Fig.6-7, the T curves were well described by three separate peaks centered at approximately 10-70 ms, $10-500 \mathrm{~ms}$ and 500-3000 ms, revealing bound water, immobilized water, and free water, respectively. Among them, immobilized water, which reflected the trapped water molecules within the three-dimensional network, dominated the gel systems.

When $\mathrm{H}$ atom was on different molecules or in samples under different physical states, its relaxation time will be different. It could be seen from the Fig. 6 that the relaxation time of three kinds of water in the gel added with PFGS at the 0th day of gel formation was significouldtly delayed. The addition of PFGS enhanced the stability of the gel. The delay in relaxation time proved that PFGS played a role in strengthening the water molecules of the gel. The reason may be that some gel molecules formed a spatial structure with more bound water with PFGS during polymerization, or that the reaction of PFGS with a large number of hydroxyl groups in the formation stage of the gel made $\mathrm{H}$ atoms more exposed.

Fig.7 and Table 1-5 showed the detection diagrams of five samples over time. It could be seen that only the relaxation time of $T_{1}$ and $T_{2}$ was advanced again in the fifth day and later detection. The reason may be that the hydroxyl of PFGS and gel molecules formed a more stable bound water under the action of air oxidation. In other words, PFGS induced the conversion of free water to immobilized water. Therefore, water mobility in the PG was somehow restricted. This phenomenon may be attributed to the wellaggrega.

It could be seen from the Fig. 8 that on day 0 , although the parameter was set as $1 \mathrm{~cm} \times 1 \mathrm{~cm} \times 1 \mathrm{~cm}$, the volume measured by SPRS decreases. Therefore, it was believed that the gel formed after the addition of PFGS had a closer spatial structure, and the gel density was also larger. Water molecules were not easy to volatilize, and the water retention was stronger. Before 10 days, the gel volume was positively correlated with the amount of PFGS added. After 10 days, the gel volume decreased rapidly with the addition of 0.15 and $0.20 \mathrm{~g} / \mathrm{kg}$ PFGS, but still higher than the blank contrast. Therefore, it could be inferred that at the concentration of 0-0.2 g / kg PFGS, the water retention of low-concentration gels was more stable over time, and high-concentration PFGS had better water retention in the short term, but the water retention decreased in the long term.

\subsection{Raman spectroscopy}

Recently many studies had used Raman spectroscopy to reflect information about the secondary and tertiary structure of protein gel. The gel properties were related to changes of the secondary structure ${ }^{9}$. Generally, the Raman spectral bands of amide I (1600-1700 cm-1$)$ and amide III (1200-1300 cm$\left.{ }^{-1}\right)$ were used for measuring the secondary structure ${ }^{10,11}$. The MPs gel of high percent of $a$-helix, $\beta$-sheet, random 
coil and $\beta$-turn could be severally appointed at $1650-1658 \mathrm{~cm}^{-1}, 1665-1680 \mathrm{~cm}^{-1}, 1660-1665 \mathrm{~cm}^{-1}$ and $1680-1690 \mathrm{~cm}^{-1} 12,13$.

Fig. 9 and Fig. 10 showed Raman spectra of gels treated with different concentrations PFGS. The bands of amide I centered at $1652 \mathrm{~cm}^{-1}$ and the bands of amide $\nabla$ centered at $1234 \mathrm{~cm}^{-1}$ (Fig. 11 and Fig. 12) were fitted through Gaussian curve and Fourier self-deconvolution (FSD) to analyze the structure of the protein. The band of $1652,1663,1674$, and $1683 \mathrm{~cm}^{-1}$ respectively indicated a-helix, random coil, $\beta$-sheet and $\beta$ turn $^{14} .1235 \pm 10 \mathrm{~cm}^{-1}$ wavelength in the amide III region showed $\beta$-folding. The wavelength of 920-1180 $\mathrm{cm}^{-1}$ (Fig.13) was $\mathrm{N}-\mathrm{Ca}-\mathrm{C}$ skeleton stretching vibration, which was classified as amide mode by some authors. Wavelength $1400-1500 \mathrm{~cm}^{-1}$ was the $\mathrm{CaH}_{2}$ bending mode of glycine or serine and wavelength 1509-1592 $\mathrm{cm}^{-1}$ (Fig.14) was the amide II region

On the 0th day of gel formation, the addition of PFGS was positively correlated with the strength range of $\mathrm{N}-\mathrm{Ca}-\mathrm{C}$ skeleton stretching vibration, which was most likely due to the large amount of $\mathrm{C}=\mathrm{O}$, hydroxyl or benzene ring in Proanthocyanidins that enhanced the $\mathrm{Ca}-\mathrm{C}$ strength of certain amino acids in the gel. However, with the passage of time, the strengthening effect of PFGS gradually weakened, and the higher the concentration was, the stronger the strengthening effect at the beginning was, and the faster the strengthening effect decreased with time.

It could be seen from the figure that $\beta$-sheet of amide 1 band $1673.892 \mathrm{~nm}^{-1}$ (Fig.15) and amide II band $1234.649 \mathrm{~nm}^{-1}$ formed gel on the 0th day, $\beta$-sheet increased with the increase of concentration. This was probably because the polymerization of PFGS in the formation process takes away the charge of some amino acids in the gel. With the decrease of the same charge and the increase of the different charge, the $\beta$-sheet formed between the peptide chains becomes stronger and more stable. But with the passage of time, especially in 5-10 days, $\beta$-sheet had a rapid downward trend, after 10 days continue to decline slowly, may be the gel hydrogen bond or S-S was oxidized broken, resulting in gel instability.

As could be seen from the Fig.11, a-helix had little effect after adding PFGS The reduction of the amide I band at around $1650 \mathrm{~cm}^{-1}$ meant a decrease of total a-helix content. The decrease might be caused by the damage of considerable amounts of a-helix conformation that accounted for the major part of MPs. It should be pointed out that the peptide bonds in the a-helix conformation may form hydrogen bonds, and therefore, a-helix was very stable. In this study, the a-helix conformation largely despiralized after adding PFGS. The exposure of intramolecular hydrophobic groups appears to be conducive to formation of gel networks and appearance of new protein folding after despiralization. As a result, the enhancement of hydrophobic effects and gelation was promoted.

In the amide II region, there were $\mathrm{N}-\mathrm{H}$ in-plane bending, $\mathrm{C}-\mathrm{N}$ stretching, $\mathrm{C}-\mathrm{O}$ in-plane bending and $\mathrm{C}-\mathrm{C}$ stretching ${ }^{15,16}$. With the addition of PFGS, the intensity of detection in the amide II region was also enhanced, possibly due to the presence of $\mathrm{C}-\mathrm{C}, \mathrm{C}-\mathrm{O}$ and a large number of benzene rings in the Proanthocyanidins molecule. However, the strength in the amide II region still increased over time. The 
possible reason was that oxidation and dehydration expose the $\mathrm{C}-\mathrm{C}$ expansion and $\mathrm{C}-\mathrm{O}$ in-plane bending of the amide II region, thus detecting greater strength.

In the Raman spectrum, the $\mathrm{C}-\mathrm{H}$ bond stretching vibration of aliphatic residues exists at $2500-3000 \mathrm{~cm}^{-}$ 117, 18. From Fig.10, it could be seen that the sample has a strong peak at $2930 \mathrm{~cm}^{-1}$, and compared with the blank contrast, the PFGS processing had a certain effect on the aliphatic $\mathrm{C}-\mathrm{H}$ stretching vibration in

the MP Raman spectrum ${ }^{19}$. With the gradual increase in the amount of PFGS, the more aliphatic residues are exposed after the protein was reversed, and more aliphatic residues appear, thereby promoting the hydrophobic interaction at the protein interface ${ }^{20,21}$. The results show that as the concentration of PFGS increases, the gel has greater hydrophobic interaction and gelling properties. But the peak in the blank contrast detected on day 0 was larger than the PG group, because the blank contrast contained more free water and the binding water.

\subsection{Rheological properties}

Storage modulus $\left(G^{\prime}\right)$ and loss modulus $\left(G^{\prime \prime}\right)$ were important indicators of gel viscoelasticity. Dynamic rheological analysis was very useful for the study of protein functional properties during muscle processing, and it was helpful to study the gel formation process, which was the basis for the formation of good texture. The $\mathrm{G}^{\prime}$ represents the energy change caused by the change of elastic deformation in the gel structure, and the $\mathrm{G}^{\prime \prime}$ represents the change of viscosity during heating.

It could be seen from Fig.16-a and Fig.16-b that the G' gradually decreases with the increase of temperature, reaching the lowest point at $48^{\circ} \mathrm{C}$. Then continue to rise to $80^{\circ} \mathrm{C}, \mathrm{G}^{\prime}$ continued to increase to a stable state, The study 22,23 also found similar results. The increase of $\mathrm{G}^{\prime}$ indicates the initial formation of gel or elastic protein network structure. The temporary decrease of $\mathrm{G}^{\prime}$ before $48^{\circ} \mathrm{C}$ was due to the expansion and crosslinking of myosin heavy chain, possibly due to the denaturation of myosin tail, mainly involving the dissociation of non-covalent bonds and the temporary interaction between molecules, thereby increasing the mobility of myosin. After further heating up, the formation of hydrophobic groups and the interaction of disulfide bonds increase the interaction of protein aggregates and form a good silk structure, which leads to the increase of $\mathrm{G}^{\prime}$, indicating that the viscous sol state changes to the elastic gel network structure. Then, the $\mathrm{G}^{\prime}$ increased rapidly and reached a steady state at $72^{\circ} \mathrm{C}$, which indicated that the gel network structure was completely formed.

When the PG concentration was higher than $0.05 \mathrm{~g} / \mathrm{kg}$, the G' starting point and final point of PG were higher than those of the blank control group, indicating that the gel strength increased with the addition of PFGS. When the addition amount was $0.25 \mathrm{~g} / \mathrm{kg}$, it was found that there was a peak at $64.8{ }^{\circ} \mathrm{C}$, and then $\mathrm{G}^{\prime}$ continued to increase, indicating that substances with very weak strength were formed at $0.25 \mathrm{~g} /$ $\mathrm{kg}$ concentration. The samples after rheological completion were observed, which was consistent with the normal formation of gel in visual observation, and the morphology was flocculent condensation block. 
With the addition of PFGS, G" also showed an upward trend, and G' was more than five times that of G". With the increase of temperature, it reached the peak at about $70^{\circ} \mathrm{C}$, and then showed a downward trend. When the addition amount was $0-0.20 \mathrm{~g} / \mathrm{kg}$, the viscosity of the gel increased with the increase of the addition amount and was higher than that of the blank contrast. However, when the addition amount was greater than or equal to $0.25 \mathrm{~g} / \mathrm{kg}$, the viscosity of PG was lower than that of the blank control.

The frequency scouldning in Fig.16-c and Fig.16-d showed that the average G' and G" of PG increase with the addition of PFGS and scouldning frequency in the concentration range of $0-0.20 \mathrm{~g} / \mathrm{kg}$. However, it could be seen from $0.20 \mathrm{~g} / \mathrm{kg} \mathrm{PG}$ that the gel had shown certain instability, and the data were extremely low at $0.25 \mathrm{~g} / \mathrm{kg}$. At the same time, the data of G' / G" could be obtained from Fig.17-f. When the addition amount was $0.05 \mathrm{~g} / \mathrm{kg}$, the composite viscosity data of PG and the blank contrast had no significouldt difference. When the addition amount was $0.05-0.20 \mathrm{~g} / \mathrm{kg}$, it could be seen that the addition of PFGS enhanced the strength of the gel, but there was also instability at $0.20 \mathrm{~g} / \mathrm{kg}$. With the addition of PFGS, the hardness and viscosity of the gel increased, but PG had instability at $0.20 \mathrm{~g} / \mathrm{kg}$, which was consistent with the detection of texture, Raman, and infrared.

It could be seen from Fig.17-e that with the increasing amount of Pas, the Persistence of CMPG continues to increase and collapses at $0.25 \mathrm{~g} / \mathrm{kg}$, which was the same trend as the gel in rheology. Fig-g was the change trend of Storage modulus and Loss modulus with temperature and Pas addition. Comparing Fig.17-h, it could be seen that the change of Fig.17-g was not very stable. The error may be the temperature change of the heater. Caused by unevenness. The $\mathrm{Hz}$ change in Fig-h was a stable digital control, so the change trend was relatively stable. Fig.17-h and g could see that with the continuous increase of temperature, frequency and Pas addition, the storage modulus and Loss modulus of the gel were all increasing, but the growth rate of Storage modulus was significantly higher than that of Loss modulus, which proves that it was heating A gel was formed during the process, and it shows a certain degree of gel stability during frequency scanning

\subsection{Microstructure}

Fig.19-A was the 0th day of blank contrast, Fig.19-B was the 20th day of blank contrast, Fig.19-C was the 0th day of $0.20 \mathrm{~g} / \mathrm{kg} \mathrm{PG}$, and Fig.19-D was the 20th day of $0.20 \mathrm{~g} / \mathrm{kg} \mathrm{PG}$.

By comparing the microscopic images of the blank contrast and the original anthocyanin group at day 0 , It was evident that the pure gel exhibited a rough surface with a disordered structure, implying that protein molecules were not fully unfolded and not welllinked to each other during gelation. With PFGS incorporation, the gel network became more regular and homogeneous with compact pores Fig.19-C. Overall, PFGS induced the development of a stable three-dimensional gel network. A highly interconnected and compact network structure might exhibit greater resistance to external stress and provide more space for entrapping water via capillary effects, thereby increasing gel strength and LFNMR. In addition, based on the self-agglomeration effect of PFGS, the agglomerated PFGS could act as fillers to fill the network structure, and these filling effects seemed to be more pronounced at higher concentrations. In Fig.20, A, B, C was a solid figure with 0.20 and 0.25, $0.50 \mathrm{~g} / \mathrm{kg}$ PFGS, respectively. It 
could be seen that with the increasing amount of PFGS, the morphology of the gel was broken, dried and irregular.

It could be seen that the surface and internal gel structure of the PG on day 0 was different, which was consistent with the problems found in LF-NMR, volume and texture detection of the block. Consideration may be caused by excessive contact between the epidermis of the outer layer of the gel and the solution during gel formation. So the PG removed all the surface gel on day 0 . On the 20th day, it could be seen 20th day that a large area of collapse occurred in both groups of gels.

Carbonyl formation was commonly used as an indicator of the oxidative stability of proteins in biological systems 24,25 , and was often used as a marker of the oxidative stability in meat products ${ }^{26,27}$. When the carbonyl group in the protein was formed, the function and structural properties of the protein will be impaired. Since there were many ways to form carbonyl groups, including amino acid side chain modification of especially proline, arginine, lysine, and threonine residues, and might lead to cross-linking or release of free carbonyls from the amino acid side chains ${ }^{24}$. Therefore, it was difficult to fundamentally inhibit the formation of carbonyl groups ${ }^{28}$. The only way to reduce the formation of carbonyl groups was to add antioxidant substances ${ }^{29,30}$. Once the carbonyl group was formed, it could not be reduced, and other thiol-derived oxidation products might also be formed, which will further damage the protein.

\section{Conclusion And Discussion}

According to existing reports ${ }^{31}$, many studies favor high concentrations of catechins without considering and comparing the limits of commonly used additives in national standards. Studies had shown that when adding $10 \mu \mathrm{mol} /$ L PFGS, a significouldt loss of thiols (S-H) content was observed in MP in the presence of catechin. This was consistent with the gel observed in the study when PFGS exceeded $0.20 \mathrm{~g} / \mathrm{kg}$. And catechin at higher concentrations (50,100 and $200 \mu \mathrm{mol} / \mathrm{g}$ protein) caused severe deterioration of MP gelation, which may be due to the PFGS - MP covalent interactions and the exposure of hydrophobic domains caused by catechin.

However, published studies ${ }^{32}$ had shown that the addition of catechins or proanthocyanidins had a strengthening effect on 3D printing materials, and the addition had better printability and gelability. Studies ${ }^{33}$ had shown that proanthocyanidins could reduce the surface hydrophobicity of gel, thereby changing the secondary structure of proteins. Studies ${ }^{34}$ had shown that the addition of proanthocyanidins could protect meat products from UV-induced light damage, which was an effective strategy to reduce UV-induced oxidative damage. The proanthocyanidins added in this study were derived from natural substances, and they were also tested according to the addition range of national standards. Therefore, the test results had practical production value. When the addition levels were 0 $0.10 \mathrm{~g} / \mathrm{kg}$ and $0.10-0.20 \mathrm{~g} / \mathrm{kg}$, the gel showed different but similar strengthening gel structure, improving gel hardness and viscoelasticity, and had more compact spatial structure, stronger water locking ability and slower failure rate compared with the blank contrast. 
This study provides new ideas for future research and future food additives, and provides valuable improvement guidelines for personalized meat products. Evaluation of its nutritional value needs further study.

\section{Materials And Methods}

\subsection{Materials}

Fresh chicken breast was purchased from a local supermarket in Qingdao, China. Catechin, Procyanidin dimer and Procyanidin tetramer was purchased from QILU PHARMACEUTICAL and the purity reached 99.9\%. Grape seed was purchased from Château Zhuoqi in Yantai, Shandong Province, China. HPLCgrade ethanol, vanillin and methanol were obtained from Fisher Scientific (Fairlawn, NJ, USA).

All the experiments were performed in accordance with relevant guidelines and regulations.

\subsection{Proanthocyanidins preparation}

$20 \mathrm{~g}$ grape seeds were grinded by refrigeration-rubbing machine, and the milled powder passed 100 mesh sieve. The filtered powder was extracted by Soxhlet extractor for 8 hours to remove lipids. After that, the powder was freeze-dried by vacuum freeze-drying machine(BIOCOOL, Pilot 3-6E, China). The freeze-dried powder was removed and added into $50 \%$ ethanol with a material liquid ratio 1:14. The solution was added $0.56 \mathrm{~g} / \mathrm{L}$ cellulase and doused for 30 minutes. After that, the solution was treated in Mar.6 microwave digestion (flexiWAVE, Japen) with microwave processing time $6 \mathrm{~min}$, microwave power $800 \mathrm{~W}$ and microwave temperature $60^{\circ} \mathrm{C}^{35}$. The solution after microwave processing was centrifuged for $10 \mathrm{~min}$ at $4^{\circ} \mathrm{C}, 8000 \mathrm{r} / \mathrm{min}$, then the supernatant tested 6 times.

Concentration of proanthocyanidins detected by the method of vanillin-hydrochloric acid. Vanillin $40 \mathrm{~g}$ dissolved in methanol to $1 \mathrm{~L}$ named Vanillin-methanol(VM) solution. Catechin standard solutions with concentrations of $50 \mathrm{ug} / \mathrm{mL}, 100 \mathrm{ug} / \mathrm{mL}, 150 \mathrm{ug} / \mathrm{mL}, 200 \mathrm{ug} / \mathrm{mL}$ and $250 \mathrm{ug} / \mathrm{mL}$ were prepared. 1 $\mathrm{mL}$ standard solution of catechin, $6 \mathrm{~mL}$ VM solution and $3 \mathrm{~mL}$ concentrated hydrochloric acid were added in turn, then the mixed solution was placed in the temperature-controlled magnetic stirrer at $4^{\circ} \mathrm{C}$ for $15 \mathrm{~h}$. The mixed solution of VM solution : methanol : concentrated hydrochloric acid = 6:1:3 was used as the blank contrast, and the absorbance was measured at $500 \mathrm{~nm}$ by ultraviolet spectrophotometer.

$\alpha=(c \times d \times v) /(m \times 1000)$

a was the extraction rate of PFGS. $c$ was the concentration obtained by regression equation $(\mathrm{mg} / \mathrm{mL})$. $\mathrm{d}$ was the dilution multiple. $v$ was the volume of liquid to be measured $(\mathrm{mL}) . \mathrm{m}$ was the mass of grape seed extract after freeze-drying (g).

The PFGS were detected by high performance liquid chromatography with fluorescence detector (HPLCFLD). The column used was a $250 \mathrm{~mm} \times 4.6 \mathrm{~mm}, 5 \mu \mathrm{m}$ (Thermo Fisher). The binary mobile phase 
consisted of $(A) \mathrm{CH}_{3} \mathrm{CN}: \mathrm{HOAc}(98: 2, \mathrm{v} / \mathrm{v})$ and $(\mathrm{B}) \mathrm{CH}_{3} \mathrm{OH}: \mathrm{H}_{2} \mathrm{O}: \mathrm{HOAc}(95: 3: 2, \mathrm{v} / \mathrm{v} / \mathrm{v})$. Separations were effected by a linear gradient at $30^{\circ} \mathrm{C}$ with a $1.5 \mathrm{~mL} / \mathrm{min}$ flow rate as follows: $0-20 \mathrm{~min}, 0-40 \% \mathrm{~B} ; 20$ $25 \mathrm{~min}, 0 \% \mathrm{~B}$, followed by a $5 \mathrm{~min}$ reequilibration time. Eluent was monitored by fluorescence detection with excitation at $276 \mathrm{~nm}$ and emission at $316 \mathrm{~nm}$. Samples were dissolved in acetone : water : acetic acid (70:29.5:0.5, v/v/v) and filtered through $0.22 \mu \mathrm{m}$ PTFE syringe filters prior to injection.

\subsection{Gel preparation}

$100 \mathrm{~g}$ chopped chicken breast mixed with 10 vol cold buffer $(25 \mathrm{mM} \mathrm{NaCl}, 5 \mathrm{mM}$ EDTA and $5 \mathrm{mM}$ Tris $\mathrm{HCl}$, $\mathrm{pH}=7.5$ ), then the mixture was broken by a crusher for 10 seconds. The mixture in the crusher was centrifuged at $10000 \mathrm{~g}, 4^{\circ} \mathrm{C}$ for 10 minutes and the supernatant was discarded. Precipitation was mixed with $5 \mathrm{vol} 0.1 \mathrm{M} \mathrm{NaCl}$ solution ( $5 \mathrm{mM}$ EDTA and $5 \mathrm{mM}$ Tris $\mathrm{HCl}, \mathrm{pH}=7.5$ ) and $0.5 \%$ Triton $\mathrm{X}-100$. Then the solution was homogenized for one minute at $8000 \mathrm{r} / \mathrm{min}$ and centrifuged at $10000 \mathrm{~g}$ for 10 minutes. After discarding the supernatant, the precipitate was suspended in $5 \mathrm{vol} 0.1 \mathrm{M} \mathrm{NaCl}$ solution ( $5 \mathrm{mM}$ EDTA-Na2 and $5 \mathrm{mM}$ Tris $\mathrm{HCl}, \mathrm{pH}=7.5$ ), and the connective tissue and lipids were removed by three-layer gauze filtration. After the solution was centrifuged at $10000 \mathrm{~g}$ for $10 \mathrm{~min}$, it was washed three times with cold distilled water. Then the precipitation was placed in a freeze-drying machine (BIOCOOL, Pilot 3-6E, China) until freeze-drying $\left(-80^{\circ} \mathrm{C}, 0.01 \mathrm{MPa}\right)$. The freeze-dried myofibrillar protein $(\mathrm{MP})$ was ground in a cryomill for 10 minutes at $4^{\circ} \mathrm{C}$.

The extracted MP powder was mixed with phosphate buffer solution (PBS, $0.6 \mathrm{~mol} / \mathrm{L} \mathrm{NaCl} \otimes 20 \mathrm{mmol} / \mathrm{L}$ $\mathrm{Na}_{2} \mathrm{HPO}_{4} / \mathrm{NaH}_{2} \mathrm{PO}_{4} \mathrm{pH}=7.0$ ) to form MP solution with concentration of $100 \mathrm{mg} / \mathrm{mL}$. The $50 \mathrm{~mL} \mathrm{MP}$ solution was placed in $80 \mathrm{~mL}$ beaker. At this point, the $0.05,0.10,0.15,0.20 \mathrm{~g} / \mathrm{kg} \mathrm{NaNO}_{2}$ and $0.05,0.10$, $0.15,0.20,0.25 \mathrm{~g} / \mathrm{kg}$ PFGS were added to the beaker respectively. And it was kept in a water bath at a speed of $1{ }^{\circ} \mathrm{C} / \mathrm{min}$ from room temperature to $80^{\circ} \mathrm{C}$ in darkness at a constant temperature of $80^{\circ} \mathrm{C}$ for 30 $\min$. Then the beaker was transferred to $-20^{\circ} \mathrm{C}$ and cooled for $10 \mathrm{~min}$, and the liquid was discarded. The remaining lumps were synthetic gels. Protein purity was calculated using the formula: $\mathrm{P} \%=$ detected protein content (after treatment) / initial protein content (before treatment).

\subsection{Dynamic Light Scattering (DLS) measurement}

The DLS measurement was performed according to the methods introduced by some research ${ }^{36,37}$, with slight modifications. The aqueous (ultrapure water) suspension of ground MP powder was set at $0.1 \%$ $(\mathrm{w} / \mathrm{v})$ at room temperature, followed by ultrasonication with low intensity $\left(<0.15 \mathrm{~W} / \mathrm{cm}^{2}\right)$ at a power of $100 \mathrm{~W}$ for $20 \mathrm{~min}$ for pre-dispersion using an ultrasonic oscillator (SBL-72DTY, SCIENTZ, China) at an initial temperature of $25 \pm 2{ }^{\circ} \mathrm{C}$. After that, hydrodynamic diameters of MP particles were determined using the auto-correlation function based on a single exponential fit to obtain the mean particle size (Zaverage diameter). Each sample was measured with a detection angle of $90^{\circ}$ at $25 \pm 0.1^{\circ} \mathrm{C}$ by a DLS (ENTASIZER, Nano - ZS90, China) and was measured in triplicate.

\subsection{Texture characteristics}


Textural properties of MP were measured following the method described by a research ${ }^{38}$ with some modifications using a Texture analyzer (TA.new plus, The USA). The prepared MP were initially cut into small cubes $(1 \mathrm{~cm} \times 1 \mathrm{~cm} \times 1 \mathrm{~cm})$. Measurements were performed at room temperature exactly $30 \mathrm{~min}$ after gelation. Hardness, chewiness and springiness were tested using a P50 probe and calculated based on the texture profile analysis (TPA) at optimal test conditions as follows: strain (40\%), trigger force (10g), pretest, test and post-test speed $(0.1,0.2,0.2 \mathrm{~mm} / \mathrm{s})$, and interval time (10s). Each sample was measured in triplicate.

\subsection{Fourier transform infrared spectrometer (FTIR) spectroscopy}

The MP were lyophilized in vacuum. The powders were analyzed at room temperature using a FTIR (Thermo Fisher, China). The scouldning wavelengths ranged from 500 to $4,000 \mathrm{~cm}^{-1}$ with a resolution of 2 $\mathrm{cm}^{-1}$ and a scouldning frequency of 128 .

\subsection{Raman spectroscopy}

The MP were analyzed at room temperature by a laser Raman spectroscope (OLYMPUS, Thermo Fisher, China) The detecting parameters were set as follows: Laser power $(10 \mathrm{~mW})$, Exposure time $(0.5 \mathrm{sec})$, Number of scoulds $(350)$, aperture $(200 \mu \mathrm{m})$, raster $(600 \mathrm{~g} / \mathrm{mm})$, scouldning area $\left(100-3,400 \mathrm{~cm}^{-1}\right)$, resolution $\left(4 \mathrm{~cm}^{-1}\right)$, and scouldning speed $\left(120 \mathrm{~cm}^{-1} / \mathrm{min}\right)$. Each sample was measured in triplicate. The microscopic images were from the Raman high resolution microscope (OLYMPUS, Thermo Fisher, China).

\subsection{Low field-nuclear magnetic resonance(LF-NMR)}

According to the method by a research ${ }^{39}, 40$, mobility and distribution of water were evaluated at $32{ }^{\circ} \mathrm{C}$ under a resonant frequency of $22.6 \mathrm{MHz}$ and a scouldning frequency of 32 for MP using a LF-NMR apparatus (NIUMAG, China). Approximately $2 \mathrm{~g}$ of MP was placed in a $\$ 15-\mathrm{mm}$ cylindrical glass tube and inserted in the NMR probe. The spin-spin relaxation time $\left(T_{2}\right)$ was measured under a t-value of $200 \mu \mathrm{s}$ between pulses of $90^{\circ}$ and $180^{\circ}$. The NMR $\mathrm{T}_{2}$ data were analyzed using the Multi-Exp Inv Analysis Software (Niumag Inc., Shanghai, China). $T_{1-2}, T_{2-3}$, and $T_{3-4}$ were the central relaxation time of responsive peaks, corresponding to water populations, and $\mathrm{P}_{1-2}, \mathrm{P}_{3-4}$, and $\mathrm{P}_{5-6}$ were the corresponding area fractions. Each sample was measured in triplicate.

\subsection{Rheological measurements}

The viscoelastic properties were evaluated by a Discovery HR-1 rheometer (Modular Compact Rheometer, China) equipped with steel parallel plate geometry ( $40 \mathrm{~mm}$ diameter and $1 \mathrm{~mm}$ gap, PP50, Pareliel plate, China). The unheated CMPG of $1.5 \mathrm{~mL}$ were placed on the plate surface and then immediately sealed with silicone oil. The constant frequency of $10 \mathrm{~Hz}$ was used to monitor the storage modulus ( $\left.\mathrm{G}^{\prime}\right)$ and loss modulus (G") under the following procedures: heating from 30 to $80^{\circ} \mathrm{C}$ at $0.5^{\circ} \mathrm{C} / \mathrm{min}^{41,42}$. Additionally, the frequency scouldning test was carried out on the gel samples at the end of heat treatment $\left(80^{\circ} \mathrm{C}\right)$, and the strain range was $0-100 \mathrm{~Hz}$. 


\subsection{Silicon pressure resistance sensor (SPRS)}

The prepared gel was cut out of $1 \mathrm{~cm} \times 1 \mathrm{~cm} \times 1 \mathrm{~cm}$ cube by ultrasonic cutting machine. Because the prepared gel had space gap, it could not be detected by ordinary drainage method or overflow method. Therefore, SPRS method was used for detection, which had high accuracy and stable data. The cut samples were put into the detector for $10 \mathrm{~s}$ and then read, which could prevent the data error caused by bubbles on the gel surface. Each sample was measured in triplicate.

\subsection{Questionnaire}

Methods a questionnaire survey was conducted among 300 students in 6 colleges, using the Gel Touch Improvement Questionnaire (GTIQ).

The experimental method follows the Nuremberg Code and the Declaration of Helsinki. This experiment was approved by Health and Safety Quarantine Center of Qingdao Agricultural University. All subjects signed the notification form, were informed of the contents of the experiment, and were given disposable medical gloves and masks. The method is to touch and squeeze the sample with a gloved hand. After touching the samples with their hands, the subjects will be disinfected

\subsection{Statistics}

Origin 2018 software was used to analyze the data.

\section{Declarations}

\section{Statement}

The Authors declare no Competing Financial or Non-Financial Interests. The Authors declare no Competing Financial Interests. The Authors declare no Competing Non-Financial Interests.

\section{Data Availability}

All the data in this paper are valid and have experimental repeatability and stability.

\section{Author Contributions}

Professor Zheng carried out the experiment and data processing part of the paper, and Professor Li wrote and revised the paper.

\section{Ethics statement}

The implementation of the research protocol complies with the "Declaration of Helsinki" and the relevant ethical requirements of the Health and Safety Quarantine Center of Qingdao Agricultural University on human research (QAUHS-00272137132, date of approval (2020/01/22)); individuals participating in the experiment are voluntary. All experimenters have fully informed consent to the experiment process, and 
signed an "Informed Consent Form" under the premise of fully understanding the experiment; the research results will be published in peer-reviewed journals or in the form of conference reports.

Author statement: We have obtained all appropriate informed consents from participants. In the informed consent form, he/she/they have agreed that his/her/their experiment results will be reported in the journal. Participants understand that their names and initials will not be published.

\section{References}

1. Lanier BQ. Unanswered questions and warnings involving anti-immunoglobulin $\mathrm{E}$ therapy based on 2-year observation of clinical experience. Allergy and asthma proceedings. 2005;26(6):435-439.

2. Cando D, Herranz B, Borderías AJ, Moreno HM. Different additives to enhance the gelation of surimi gel with reduced sodium content. Food Chemistry. 2016/04/01/ 2016;196:791-799. doi:https://doi.org/10.1016/j.foodchem.2015.10.022

3. Wongmekiat O, Peerapanyasut W, Kobroob A. Catechin supplementation prevents kidney damage in rats repeatedly exposed to cadmium through mitochondrial protection. NaunynSchmiedeberg's Archives of Pharmacology. 2018/04/01 2018;391(4):385-394. doi:10.1007/s00210-0181468-6

4. Huang M-s, Zhang M, Bhandari B, Liu Y. Improving the three-dimensional printability of taro paste by the addition of additives. https://doi.org/10.1111/jfpe.13090. Journal of Food Process Engineering. 2020/05/01 2020;43(5):e13090. doi:https://doi.org/10.1111/jfpe.13090

5. Fine AM. Oligomeric proanthocyanidin complexes: history, structure, and phytopharmaceutical applications. (1089-5159 (Print))

6. Chen X, Zou Y, Han M, et al. Solubilisation of myosin in a solution of low ionic strength Lhistidine: Significance of the imidazole ring. (1873-7072 (Electronic))

7. Guo XY, Peng ZQ, Zhang YW, Liu B, Cui YQ. The solubility and conformational characteristics of porcine myosin as affected by the presence of L-lysine and L-histidine. (1873-7072 (Electronic))

8. Wang Z, Hong C, Xing Y, Feng L, Li Y, Jia M. Influences of ultrafine comminution on chemical properties of antibiotic bioferment residue. Powder Technology. 2017/11/01/ 2017;321:514-522. doi:https://doi.org/10.1016/j.powtec.2017.08.003

9. Su Y, Dong Y, Niu F, Wang C, Liu Y, Yang Y. Study on the gel properties and secondary structure of soybean protein isolate/egg white composite gels. European Food Research and Technology. 2015/02/01 2015;240(2):367-378. doi:10.1007/s00217-014-2336-3

10. Talaikis MA-O, Strazdaite SA-O, Žiaunys M, Niaura G. Far-Off Resonance: Multiwavelength Raman Spectroscopy Probing Amide Bands of Amyloid- $\beta$-(37-42) Peptide. LID - 
10.3390/molecules25153556 [doi] LID - 3556. (1420-3049 (Electronic))

11. Paschou AM, Katsikini MA-O, Christofilos D, Arvanitidis J, Ves S. High pressure Raman study of type-I collagen. (1742-4658 (Electronic))

12. Masuda $\mathrm{T}$, Maruyama $\mathrm{H}$, Arai $\mathrm{F}$, et al. Application of an indicator-immobilized-gel-sheet for measuring the $\mathrm{pH}$ surrounding a calcium phosphate-based biomaterial. (1530-8022 (Electronic))

13. De Leon Rodriguez LM, Hemar Y, Cornish J, Brimble MA. Structure-mechanical property correlations of hydrogel forming $\beta$-sheet peptides. (1460-4744 (Electronic))

14. Xue $\mathrm{H}, \mathrm{Tu} \mathrm{Y}, \mathrm{Xu} \mathrm{M}$, et al. Changes in physicochemical properties, gel structure and in vitro digestion of marinated egg white gel during braising. (1873-7072 (Electronic))

15. Lewis En Fau - Bittman R, Bittman R Fau - Levin IW, Levin IW. Methyl group substitution at C(1), $\mathrm{C}(2)$ or $\mathrm{C}(3)$ of the glycerol backbone of a diether phosphocholine: a comparative study of bilayer chain disorder in the gel and liquid-crystalline phases. (0006-3002 (Print))

16. Lal P, Sharma D Fau - Pruthi P, Pruthi P Fau - Pruthi V, Pruthi V. Exopolysaccharide analysis of biofilm-forming Candida albicans. (1365-2672 (Electronic))

17. Herrero AM, Cambero MI, Ordóñez JA, de la Hoz L, Carmona P. Raman spectroscopy study of the structural effect of microbial transglutaminase on meat systems and its relationship with textural characteristics. Food Chemistry. 2008/07/01/ 2008;109(1):25-32.

doi:https://doi.org/10.1016/j.foodchem.2007.12.003

18. Li Y, Wang Q, Guo L, et al. Effects of ultrafine comminution treatment on gelling properties of myofibrillar proteins from chicken breast. Food Hydrocolloids. 2019/12/01/ 2019;97:105199. doi:https://doi.org/10.1016/j.foodhyd.2019.105199

19. Shao J-H, Zou Y-F, Xu X-L, Wu J-Q, Zhou G-H. Evaluation of structural changes in raw and heated meat batters prepared with different lipids using Raman spectroscopy. Food Research International. 2011/11/01/ 2011;44(9):2955-2961. doi:https://doi.org/10.1016/j.foodres.2011.07.003

20. Larsson K Fau - Rand RP, Rand RP. Detection of changes in the environment of hydrocarbon chains by Raman spectroscopy and its application to lipid-protein systems. (0006-3002 (Print))

21. Poowakanjana S, Mayer Sg Fau - Park JW, Park JW. Optimum chopping conditions for Alaska pollock, Pacific whiting, and threadfin bream surimi paste and gel based on rheological and Raman spectroscopic analysis. (1750-3841 (Electronic))

22. Sovrani V, de Jesus LI, Simas-Tosin FF, Smiderle FR, lacomini M. Structural characterization and rheological properties of a gel-like $\beta$-d-glucan from Pholiota nameko. (1879-1344 (Electronic)) 
23. Wu MA-O, Wang J, Hu J, et al. Effect of typical starch on the rheological properties and NMR characterization of myofibrillar protein gel. (1097-0010 (Electronic))

24. Headlam HA, Davies MJ. Beta-scission of side-chain alkoxyl radicals on peptides and proteins results in the loss of side-chains as aldehydes and ketones. (0891-5849 (Print))

25. Stadtman ER. Metal ion-catalyzed oxidation of proteins: biochemical mechanism and biological consequences. (0891-5849 (Print))

26. Ganhão R, Morcuende D Fau - Estévez M, Estévez M. Protein oxidation in emulsified cooked burger patties with added fruit extracts: Influence on colour and texture deterioration during chill storage. (1873-4138 (Electronic))

27. Lund MN, Hviid Ms Fau - Skibsted LH, Skibsted LH. The combined effect of antioxidants and modified atmosphere packaging on protein and lipid oxidation in beef patties during chill storage. (03091740 (Print))

28. Stadtman ER, Levine RL. Free radical-mediated oxidation of free amino acids and amino acid residues in proteins. (0939-4451 (Print))

29. Lund MN, Lametsch R Fau - Hviid MS, Hviid Ms Fau - Jensen ON, Jensen On Fau - Skibsted LH, Skibsted LH. High-oxygen packaging atmosphere influences protein oxidation and tenderness of porcine longissimus dorsi during chill storage. (0309-1740 (Print))

30. Decker EA, Xiong YL, Calvert JT, Crum AD, Blanchard SP. Chemical, physical, and functional properties of oxidized turkey white muscle myofibrillar proteins. Journal of Agricultural and Food Chemistry. 1993/02/01 1993;41(2):186-189. doi:10.1021/jf00026a007

31. Jia N, Wang L, Shao J, Liu D, Kong B. Changes in the structural and gel properties of pork myofibrillar protein induced by catechin modification. (1873-4138 (Electronic))

32. Zeng X, Li T, Zhu J, Chen L, Zheng B. Printability improvement of rice starch gel via catechin and procyanidin in hot extrusion 3D printing. Food Hydrocolloids. 2021/12/01/ 2021;121:106997. doi:https://doi.org/10.1016/j.foodhyd.2021.106997

33. Xu J, Guo S, Li X, Jiang S, Zhong X, Zheng ZA-O. Gel properties of transglutaminase-induced soy protein isolate-polyphenol complex: influence of epigallocatechin-3-gallate. (1097-0010 (Electronic))

34. Harwansh RK, Mukherjee PK, Kar A, Bahadur S, Al-Dhabi NA, Duraipandiyan V. Enhancement of photoprotection potential of catechin loaded nanoemulsion gel against UVA induced oxidative stress. (1873-2682 (Electronic))

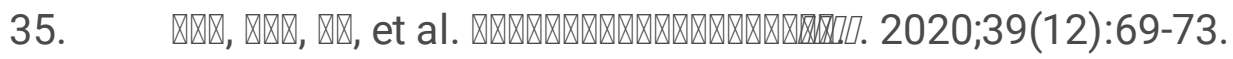


36. Chen $\mathrm{X}, \mathrm{Li}$ Y, Zhou R, et al. $\mathbb{E}$ histidine improves water retention of heat induced gel of chicken breast myofibrillar proteins in low ionic strength solution. International Journal of Food Science and Technology. 2016;51:1195-1203.

37. Shimada M, Takai E, Ejima D, Arakawa T, Shiraki K. Heat-induced formation of myosin oligomersoluble filament complex in high-salt solution. (1879-0003 (Electronic))

38. Xu XL, Han My Fau - Fei Y, Fei Y Fau - Zhou G-H, Zhou GH. Raman spectroscopic study of heatinduced gelation of pork myofibrillar proteins and its relationship with textural characteristic. (1873-4138 (Electronic))

39. Chen F, Chen $C$, Zhao D, et al. On-line monitoring of the sol-gel transition temperature of thermosensitive chitosan/ $\beta$-glycerophosphate hydrogels by low field NMR

Combined Used of Rheology and LF-NMR for the Characterization of PVP-Alginates Gels Containing Liposomes

Assessment of Water Mobility in Surf Clam and Soy Protein System during Gelation Using LF-NMR Technique. LID - 10.3390/foods9020213 [doi] LID - 213. (1879-1344 (Electronic))

40. Fanesi G, Abrami M, Zecchin F, et al. Combined Used of Rheology and LF-NMR for the Characterization of PVP-Alginates Gels Containing Liposomes. (1573-904X (Electronic))

41. Yu T, Malcolm K Fau - Woolfson D, Woolfson D Fau - Jones DS, Jones Ds Fau - Andrews GP, Andrews GP. Vaginal gel drug delivery systems: understanding rheological characteristics and performance. (1744-7593 (Electronic))

42. Berlangieri C, Poggi G, Murgia S, Monduzzi M, Dei L, Carretti E. Structural, rheological and dynamics insights of hydroxypropyl guar gel-like systems. (1873-4367 (Electronic))

\section{Tables}

Table1, day 0

\begin{tabular}{|c|c|c|c|c|c|c|}
\hline Proanthocyanidins & $\mathrm{T}_{1-2}(\mathrm{~ms})$ & $\mathrm{PT}_{1-2}(\%)$ & $\mathrm{T}_{3-4}(\mathrm{~ms})$ & $\mathrm{PT}_{3-4}(\%)$ & $\mathrm{T}_{5-6}(\mathrm{~ms})$ & $\mathrm{PT}_{5-6}(\%)$ \\
\hline $0 \mathrm{~g} / \mathrm{kg}$ & $3.51 \pm 0.01^{\mathrm{a}}$ & $\begin{array}{c}4.5 \% \\
\pm 0.38^{\mathrm{a}} \\
3.3 \%\end{array}$ & $37.64 \pm 0.04^{\mathrm{a}}$ & $\begin{array}{c}60.91 \% \\
\pm 0.44^{\mathrm{a}} \\
39.44 \%\end{array}$ & $1417.47 \pm 0.01^{\mathrm{a}}$ & $\begin{array}{c}34.58 \% \\
\pm 2.65 \mathrm{a} \\
57.25 \%\end{array}$ \\
\hline $0.05 \mathrm{~g} / \mathrm{kg}$ & $4.03 \pm 0.01^{\mathrm{a}}$ & $\begin{array}{c} \pm 0.18^{\mathrm{a}} \\
3.5 \%\end{array}$ & $43.28 \pm 0.01^{\mathrm{a}}$ & $\begin{array}{c} \pm 0.38^{\mathrm{a}} \\
52.41 \%\end{array}$ & $1417.47 \pm 0.01^{\mathrm{a}}$ & $\begin{array}{c} \pm 1.65^{\mathrm{a}} \\
44.08 \%\end{array}$ \\
\hline $0.10 \mathrm{~g} / \mathrm{kg}$ & $4.03 \pm 0.01^{\mathrm{a}}$ & $\begin{array}{l} \pm 0.37^{\mathrm{a}} \\
3.91 \%\end{array}$ & $43.28 \pm 0.01^{\mathrm{a}}$ & $\begin{array}{c} \pm 0.41^{\mathrm{a}} \\
53.88 \%\end{array}$ & $1417.47 \pm 0.01^{\mathrm{a}}$ & $\begin{array}{l} \pm 0.72^{\mathrm{a}} \\
42.21 \%\end{array}$ \\
\hline $0.15 \mathrm{~g} / \mathrm{kg}$ & $4.03 \pm 0.01^{\mathrm{a}}$ & $\begin{array}{l} \pm 0.62^{\mathrm{a}} \\
3.99 \%\end{array}$ & $43.28 \pm 0.01^{\mathrm{a}}$ & $\begin{array}{l} \pm 0.35^{\mathrm{a}} \\
54.15 \%\end{array}$ & $1629.75 \pm 0.01^{\mathrm{a}}$ & $\begin{array}{l} \pm 0.84^{\mathrm{a}} \\
41.86 \%\end{array}$ \\
\hline $0.20 \mathrm{~g} / \mathrm{kg}$ & $4.03 \pm 0.01^{\mathrm{a}}$ & $\pm 0.57^{\mathrm{a}}$ & $43.28 \pm 0.01^{\mathrm{a}}$ & $\pm 0.52^{\mathrm{a}}$ & $1417.47 \pm 0.01^{\mathrm{a}}$ & $\pm 0.51^{\mathrm{a}}$ \\
\hline
\end{tabular}

Table 2, day 5 


\begin{tabular}{ccccccc}
\hline Proanthocyanidins & $\mathrm{T}_{1-2}(\mathrm{~ms})$ & $\mathrm{PT}_{1-2}(\%)$ & $\mathrm{T}_{3-4}(\mathrm{~ms})$ & $\mathrm{PT}_{3-4}(\%)$ & $\mathrm{T}_{5-6}(\mathrm{~ms})^{\mathrm{PT}_{5-6}(\%)}$ \\
\hline $0 \mathrm{~g} / \mathrm{kg}$ & $2.66 \pm 0.0^{\mathrm{a}}$ & $5.3 \%$ & $37.64 \pm 0.04^{\mathrm{a}}$ & $62.83 \%$ & $1232.84 \pm 0.01^{\mathrm{a}}$ & $31.87 \%$ \\
& & $\pm 0.05^{\mathrm{a}}$ & & $\pm 1.58^{\mathrm{a}}$ & & $\pm 1.73^{\mathrm{a}}$ \\
$0.05 \mathrm{~g} / \mathrm{kg}$ & $3.05 \pm 0.01^{\mathrm{a}}$ & $3.57 \%$ & $43.28 \pm 0.01^{\mathrm{a}}$ & $43.85 \%$ & $1417.47 \pm 0.01^{\mathrm{a}}$ & $52.58 \%$ \\
& & $\pm 0.18^{\mathrm{a}}$ & & $\pm 2.83^{\mathrm{a}}$ & & $\pm 2.19^{\mathrm{a}}$ \\
$0.10 \mathrm{~g} / \mathrm{kg}$ & $3.05 \pm 0.01^{\mathrm{a}}$ & $3.71 \%$ & $43.28 \pm 0.01^{\mathrm{a}}$ & $55.87 \%$ & $1417.47 \pm 0.01^{\mathrm{a}}$ & $40.42 \%$ \\
& & $\pm 0.47^{\mathrm{a}}$ & & $\pm 1.71^{\mathrm{a}}$ & & $\pm 0.47^{\mathrm{a}}$ \\
$0.15 \mathrm{~g} / \mathrm{kg}$ & $3.05 \pm 0.01^{\mathrm{a}}$ & $4.07 \%$ & $43.28 \pm 0.01^{\mathrm{a}}$ & $57.21 \%$ & $1417.47 \pm 0.01^{\mathrm{a}}$ & $38.72 \%$ \\
& & $\pm 0.26^{\mathrm{a}}$ & & $\pm 2.49^{\mathrm{a}}$ & & $\pm 1.64^{\mathrm{a}}$ \\
$0.20 \mathrm{~g} / \mathrm{kg}$ & $3.05 \pm 0.01^{\mathrm{a}}$ & $4.26 \%$ & $43.28 \pm 0.01^{\mathrm{a}}$ & $72.31 \%$ & $1417.47 \pm 0.01^{\mathrm{a}}$ & $23.43 \%$ \\
& & $\pm 0.91^{\mathrm{a}}$ & & $\pm 3.51^{\mathrm{a}}$ & & $\pm 3.41^{\mathrm{a}}$ \\
\hline
\end{tabular}

Table 3, day 10

\begin{tabular}{|c|c|c|c|c|c|c|}
\hline Proanthocyanidins & $\mathrm{T}_{1-2}(\mathrm{~ms})$ & $\mathrm{PT}_{1-2}(\%)$ & $\mathrm{T}_{3-4}(\mathrm{~ms})$ & $\mathrm{PT}_{3-4}(\%)$ & $\mathrm{T}_{5-6}(\mathrm{~ms})$ & $\mathrm{PT}_{5-6}(\%)$ \\
\hline $0 \mathrm{~g} / \mathrm{kg}$ & $2.66 \pm 0.01^{\mathrm{a}}$ & $5.41 \%$ & $37.65 \pm 0.02^{\mathrm{a}}$ & $65.47 \%$ & $1232.84 \pm 0.01^{a}$ & $29.21 \%$ \\
\hline $0.05 \mathrm{~g} / \mathrm{kg}$ & $3.05 \pm 0.01^{\mathrm{a}}$ & $\begin{array}{l} \pm 0.02^{\mathrm{a}} \\
3.77 \% \\
+0.12 \mathrm{a}\end{array}$ & $43.28 \pm 0.01^{\mathrm{a}}$ & $\begin{array}{l} \pm 2.71^{\mathrm{a}} \\
46.52 \% \\
+3.98^{\mathrm{a}}\end{array}$ & $1417.47 \pm 0.01^{\mathrm{a}}$ & $\begin{array}{l} \pm 1.44^{\mathrm{a}} \\
49.71 \% \\
+1.09^{\mathrm{a}}\end{array}$ \\
\hline $0.10 \mathrm{~g} / \mathrm{kg}$ & $3.05 \pm 0.01^{\mathrm{a}}$ & $\begin{array}{l}3.89 \% \\
\pm 0.22^{\mathrm{a}}\end{array}$ & $43.28 \pm 0.01^{\mathrm{a}}$ & $\begin{array}{l}51.86 \% \\
\pm 2.41^{\mathrm{a}}\end{array}$ & $1417.47 \pm 0.01^{\mathrm{a}}$ & $\begin{array}{l}44.25 \% \\
\pm 0.51^{\mathrm{a}}\end{array}$ \\
\hline $0.15 \mathrm{~g} / \mathrm{kg}$ & $3.05 \pm 0.01^{\mathrm{a}}$ & $\begin{array}{l}4.12 \% \\
\pm 0.38 \mathrm{a}\end{array}$ & $43.28 \pm 0.01^{\mathrm{a}}$ & $\begin{array}{c}59.41 \% \\
\pm 3.98^{\mathrm{a}}\end{array}$ & $1417.47 \pm 0.01^{\mathrm{a}}$ & $\begin{array}{l}36.47 \% \\
\pm 2.72^{\mathrm{a}}\end{array}$ \\
\hline $0.20 \mathrm{~g} / \mathrm{kg}$ & $3.05 \pm 0.01^{\mathrm{a}}$ & $\begin{array}{r}4.41 \% \\
\pm 0.85^{a}\end{array}$ & $43.28 \pm 0.01^{\mathrm{a}}$ & $\begin{array}{l}69.42 \% \\
\pm 6.17^{\mathrm{a}}\end{array}$ & $1417.47 \pm 0.01^{\mathrm{a}}$ & $\begin{array}{c}26.17 \% \\
\pm 2.69^{a}\end{array}$ \\
\hline
\end{tabular}

Table4, day 15

\begin{tabular}{|c|c|c|c|c|c|c|}
\hline Proanthocyanidins & $\mathrm{T}_{1-2}(\mathrm{~ms})$ & $\mathrm{PT}_{1-2}(\%)$ & $\mathrm{T}_{3-4}(\mathrm{~ms})$ & $\mathrm{PT}_{3-4}(\%)$ & $\mathrm{T}_{5-6}(\mathrm{~ms})$ & $\mathrm{PT}_{5-6}(\%)$ \\
\hline $0 \mathrm{~g} / \mathrm{kg}$ & $2.65 \pm 0.02^{\mathrm{a}}$ & $\begin{array}{c}15.42 \% \\
+0.52 a\end{array}$ & $29.65 \pm 0.01^{\mathrm{a}}$ & $66.19 \%$ & $1232.84 \pm 0.01^{\mathrm{a}}$ & $18.39 \%$ \\
\hline $0.05 \mathrm{~g} / \mathrm{kg}$ & $3.05 \pm 0.01^{\mathrm{a}}$ & $\begin{array}{l} \pm 0.52^{\mathrm{a}} \\
13.32 \% \\
+1.18^{\mathrm{a}}\end{array}$ & $32.74 \pm 0.01^{\mathrm{a}}$ & & $1417.47 \pm 0.01^{\mathrm{a}}$ & $4 \%$ \\
\hline $0.10 \mathrm{~g} / \mathrm{kg}$ & $3.05 \pm 0.01^{\mathrm{a}}$ & $\begin{array}{l} \pm 1.18^{\mathrm{a}} \\
15.49 \% \\
\pm 0.83^{\mathrm{a}}\end{array}$ & $32.74 \pm 0.01^{\mathrm{a}}$ & $\begin{array}{l} \pm 2.48^{a} \\
63.87 \% \\
\pm 3.49^{\mathrm{a}}\end{array}$ & $1417.47 \pm 0.01^{\mathrm{a}}$ & $\begin{array}{c} \pm 1.26^{a} \\
20.64 \% \\
\pm 1.55^{a}\end{array}$ \\
\hline $0.15 \mathrm{~g} / \mathrm{kg}$ & $3.05 \pm 0.01^{\mathrm{a}}$ & $\begin{array}{l}18.78 \% \\
\pm 0.40^{\mathrm{a}}\end{array}$ & $32.74 \pm 0.01^{\mathrm{a}}$ & $\begin{array}{l}65.64 \% \\
\pm 3.81^{\mathrm{a}}\end{array}$ & $1417.47 \pm 0.01^{\mathrm{a}}$ & $\begin{array}{l}15.58 \% \\
\pm 2.40^{\mathrm{a}}\end{array}$ \\
\hline $0.20 \mathrm{~g} / \mathrm{kg}$ & $3.05 \pm 0.01^{\mathrm{a}}$ & $\begin{array}{l}20.53 \% \\
\pm 0.24^{\mathrm{a}}\end{array}$ & $32.74 \pm 0.01^{\mathrm{a}}$ & $\begin{array}{l}67.08 \% \\
\pm 2.48^{\mathrm{a}} \\
\end{array}$ & $1417.47 \pm 0.01^{\mathrm{a}}$ & $\begin{array}{l}12.39 \% \\
\pm 2.82^{\mathrm{a}}\end{array}$ \\
\hline
\end{tabular}

Table 5, day 20

\begin{tabular}{|c|c|c|c|c|c|c|}
\hline Proanthocyanidins & $\mathrm{T}_{1-2}(\mathrm{~ms})$ & $\mathrm{PT}_{1-2}(\%)$ & $\mathrm{T}_{3-4}(\mathrm{~ms})$ & $\mathrm{PT}_{3-4}(\%)$ & $\mathrm{T}_{5-6}(\mathrm{~ms})$ & $\begin{array}{l}\mathrm{PT}_{5-} \\
6(\%)\end{array}$ \\
\hline $0 \mathrm{~g} / \mathrm{kg}$ & $2.65 \pm 0.07^{\mathrm{a}}$ & $27.46 \%$ & $29.65 \pm 0.01^{\mathrm{a}}$ & $59.47 \%$ & $1232.85 \pm 0.03^{a}$ & $13.07 \%$ \\
\hline $0.05 \mathrm{~g} / \mathrm{kg}$ & $3.05 \pm 0.01^{\mathrm{a}}$ & $\begin{array}{l} \pm 1.14 \% \\
17.25 \% \\
\pm 2.11^{\mathrm{a}}\end{array}$ & $32.74 \pm 0.01^{\mathrm{a}}$ & $\begin{array}{l} \pm 3 . / 1 \% \\
66.33 \% \\
\pm 4.90^{\mathrm{a}}\end{array}$ & $1417.47 \pm 0.01^{\mathrm{a}}$ & $\begin{array}{l} \pm 1.04^{\circ} \\
16.42 \% \\
\pm 0.81^{\mathrm{a}}\end{array}$ \\
\hline $0.10 \mathrm{~g} / \mathrm{kg}$ & $3.05 \pm 0.01^{\mathrm{a}}$ & $\begin{array}{l}18.73 \% \\
+169^{a}\end{array}$ & $32.74 \pm 0.01^{\mathrm{a}}$ & $\begin{array}{r}65.14 \% \\
+2.712^{a}\end{array}$ & $1417.47 \pm 0.01^{\mathrm{a}}$ & $\begin{array}{l}16.13 \% \\
+2.10^{a}\end{array}$ \\
\hline $0.15 \mathrm{~g} / \mathrm{kg}$ & $3.05 \pm 0.01^{\mathrm{a}}$ & $\begin{array}{c}24.57 \% \\
+2.27^{a}\end{array}$ & $32.74 \pm 0.01^{\mathrm{a}}$ & $\begin{array}{l}61.98 \% \\
+6.04^{\mathrm{a}}\end{array}$ & $1417.47 \pm 0.01^{\mathrm{a}}$ & $\begin{array}{l}13.45 \% \\
+1.71^{\mathrm{a}}\end{array}$ \\
\hline $0.20 \mathrm{~g} / \mathrm{kg}$ & $3.05 \pm 0.02^{\mathrm{a}}$ & $\begin{array}{c}28.53 \% \\
\pm 3.81^{\mathrm{a}}\end{array}$ & $32.74 \pm 0.01^{\mathrm{a}}$ & $\begin{array}{l}60.61 \% \\
\pm 7.15^{\mathrm{a}}\end{array}$ & $1417.47 \pm 0.02^{\mathrm{a}}$ & $\begin{array}{l}10.86 \% \\
\pm 3.01^{\mathrm{a}}\end{array}$ \\
\hline
\end{tabular}

\section{Figures}




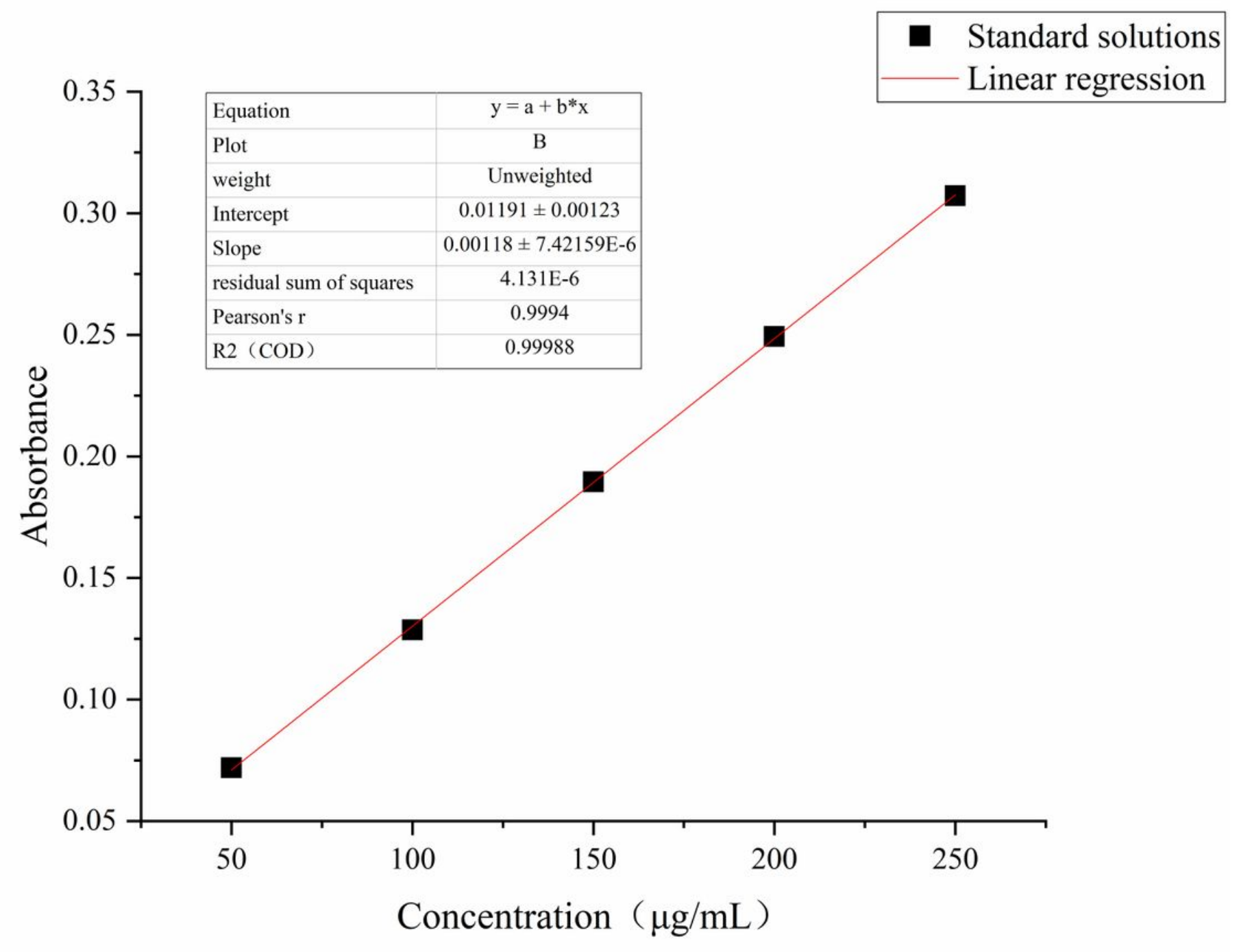

Figure 1

Catechin standard curve 


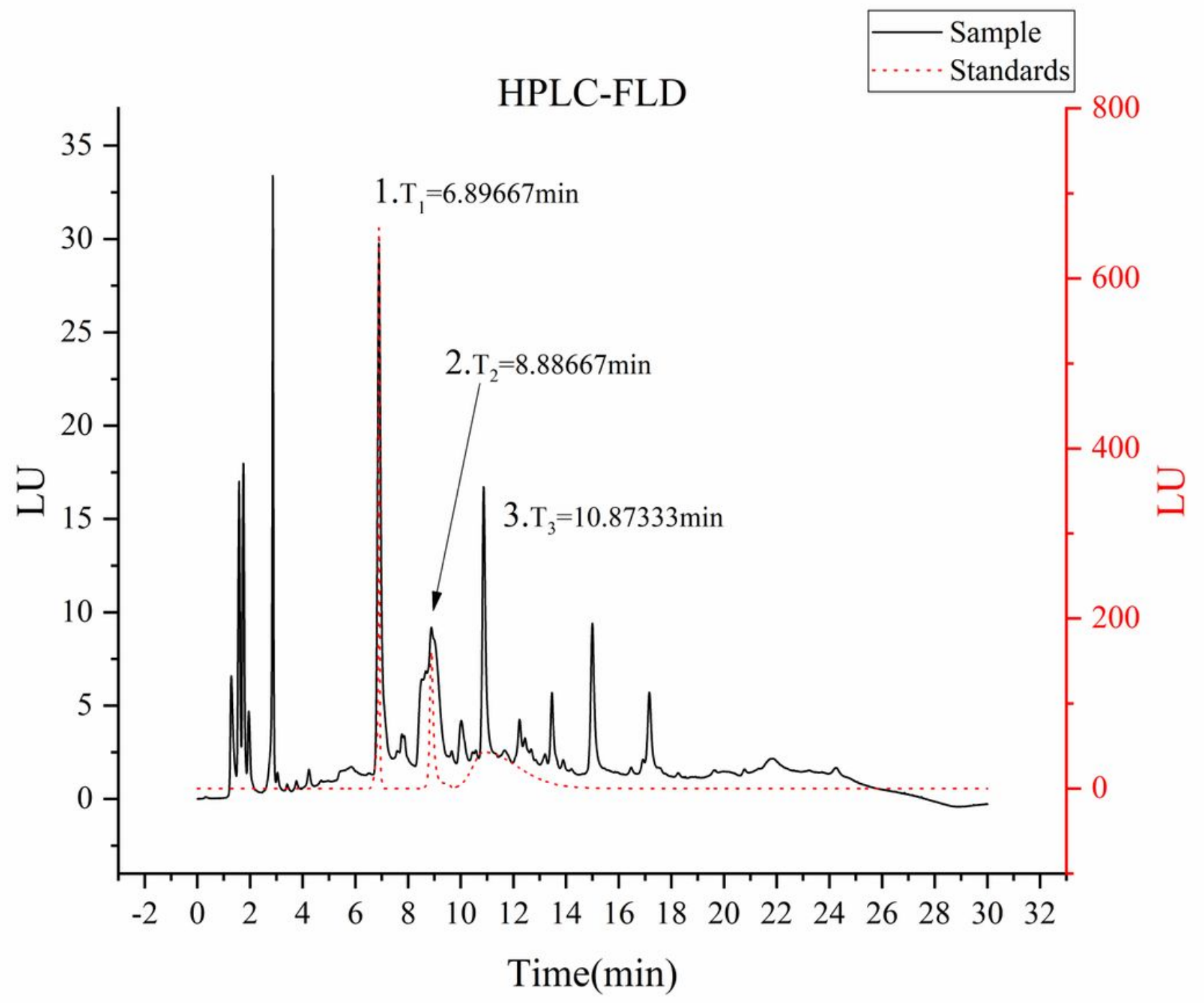

Figure 2

HPLC-FLD 


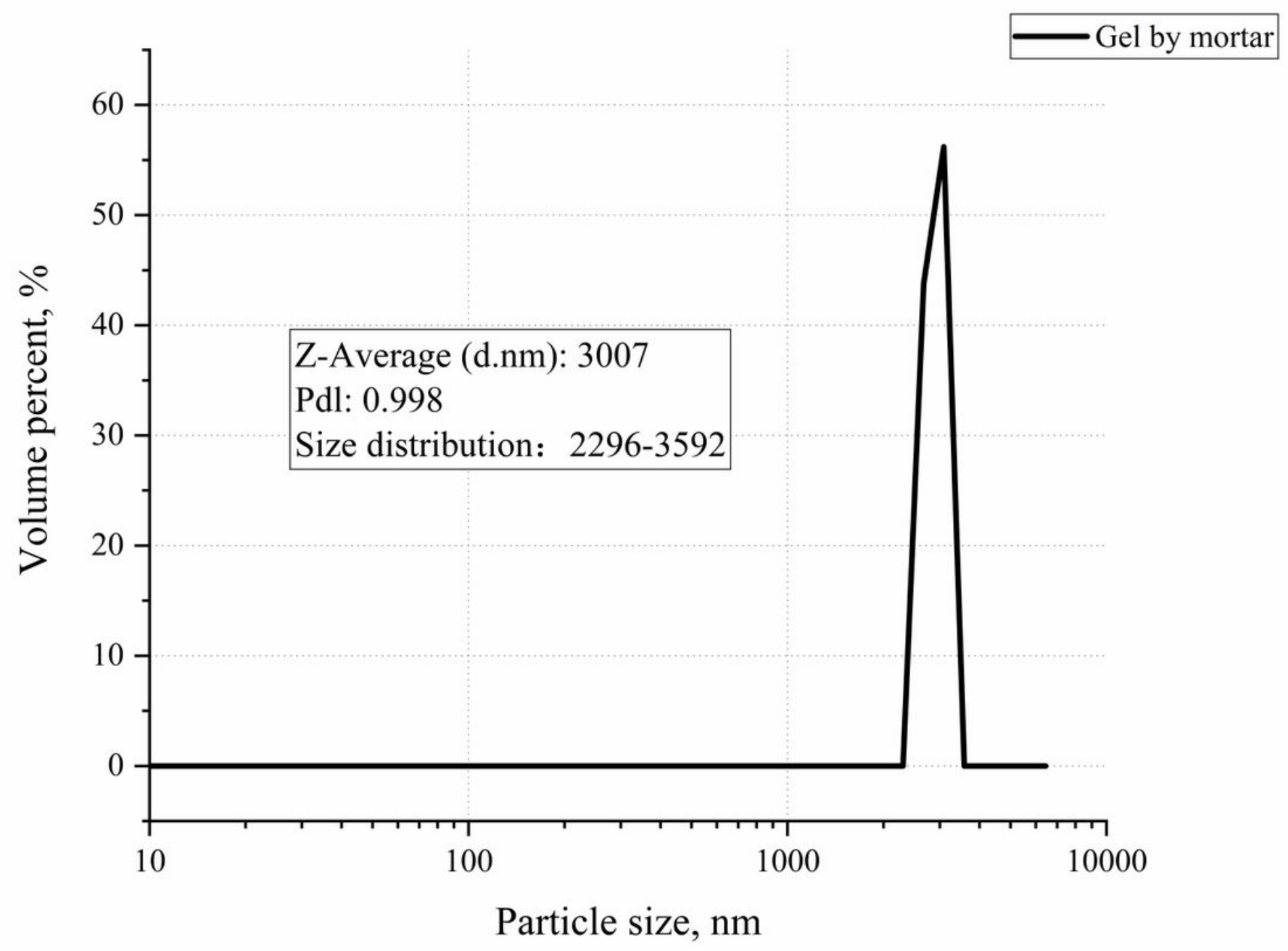

Figure 3

DLS 

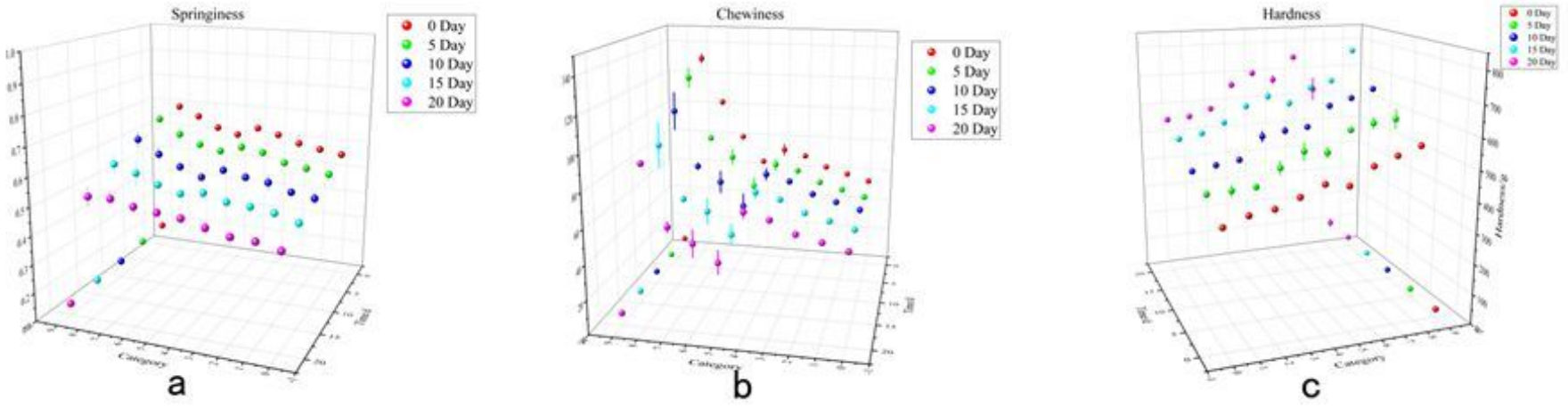

Figure 4

Texture characteristics 


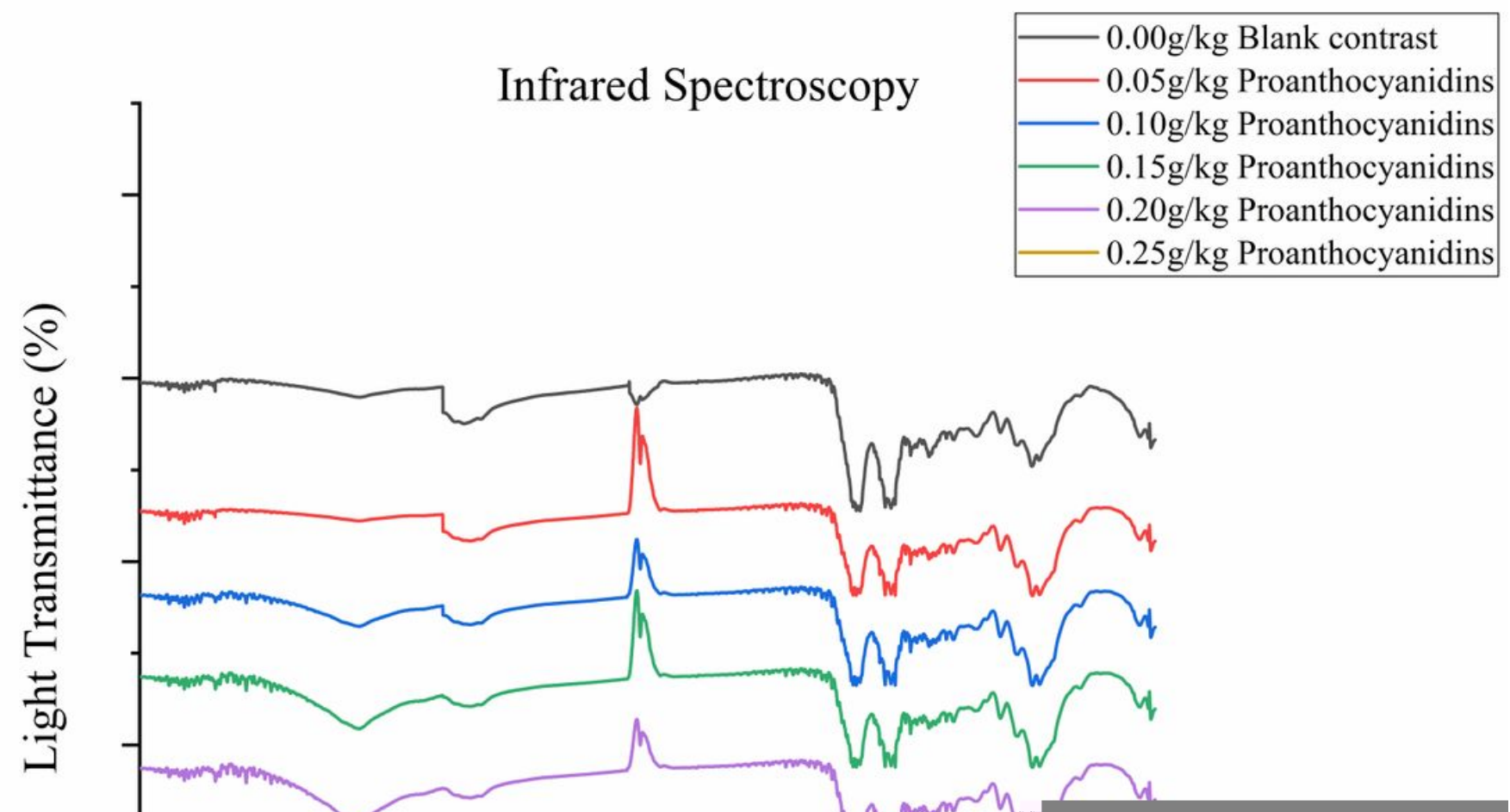

Figure 5

FTIR 


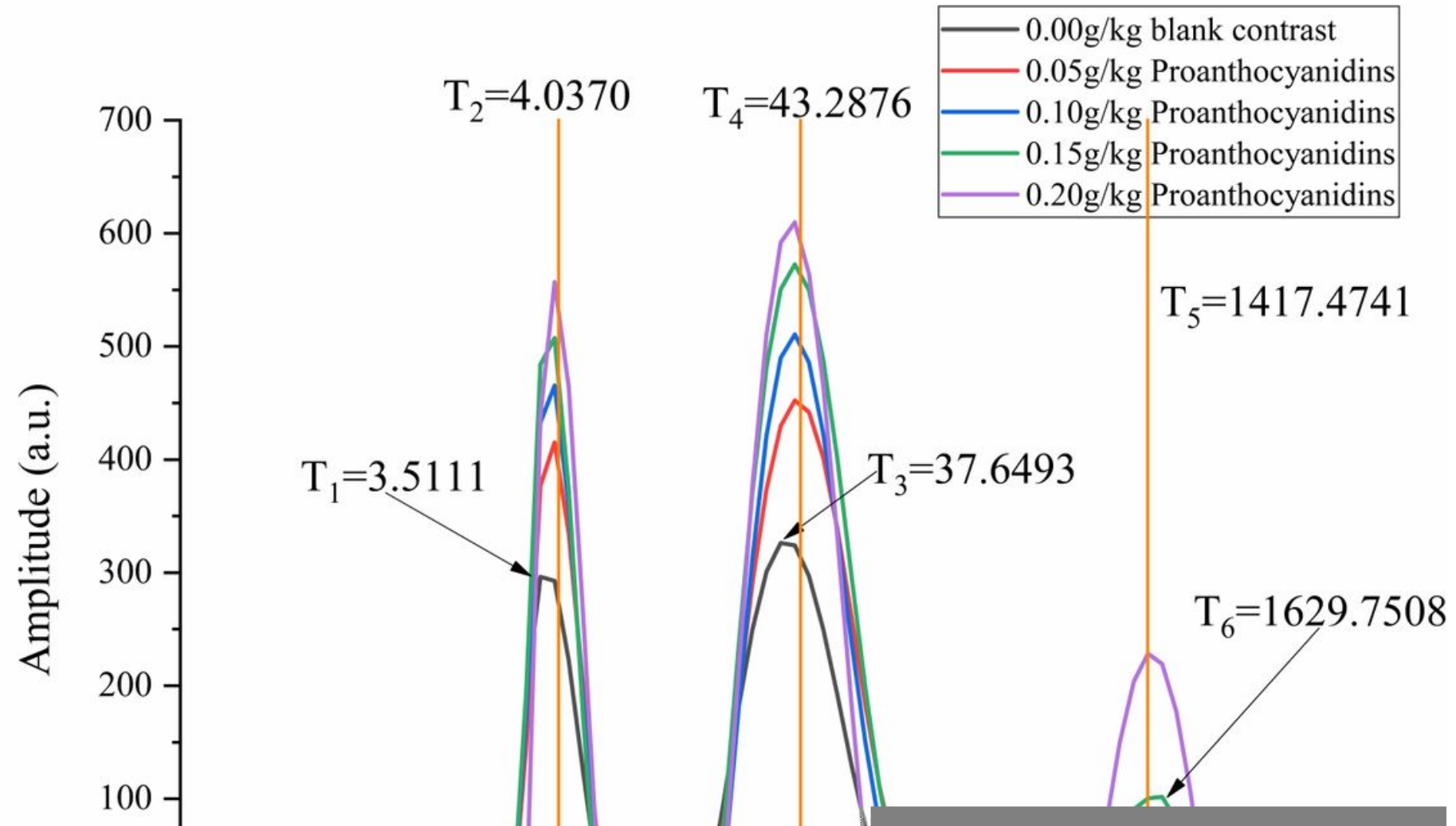

Figure 6

LF-NMR the first day 


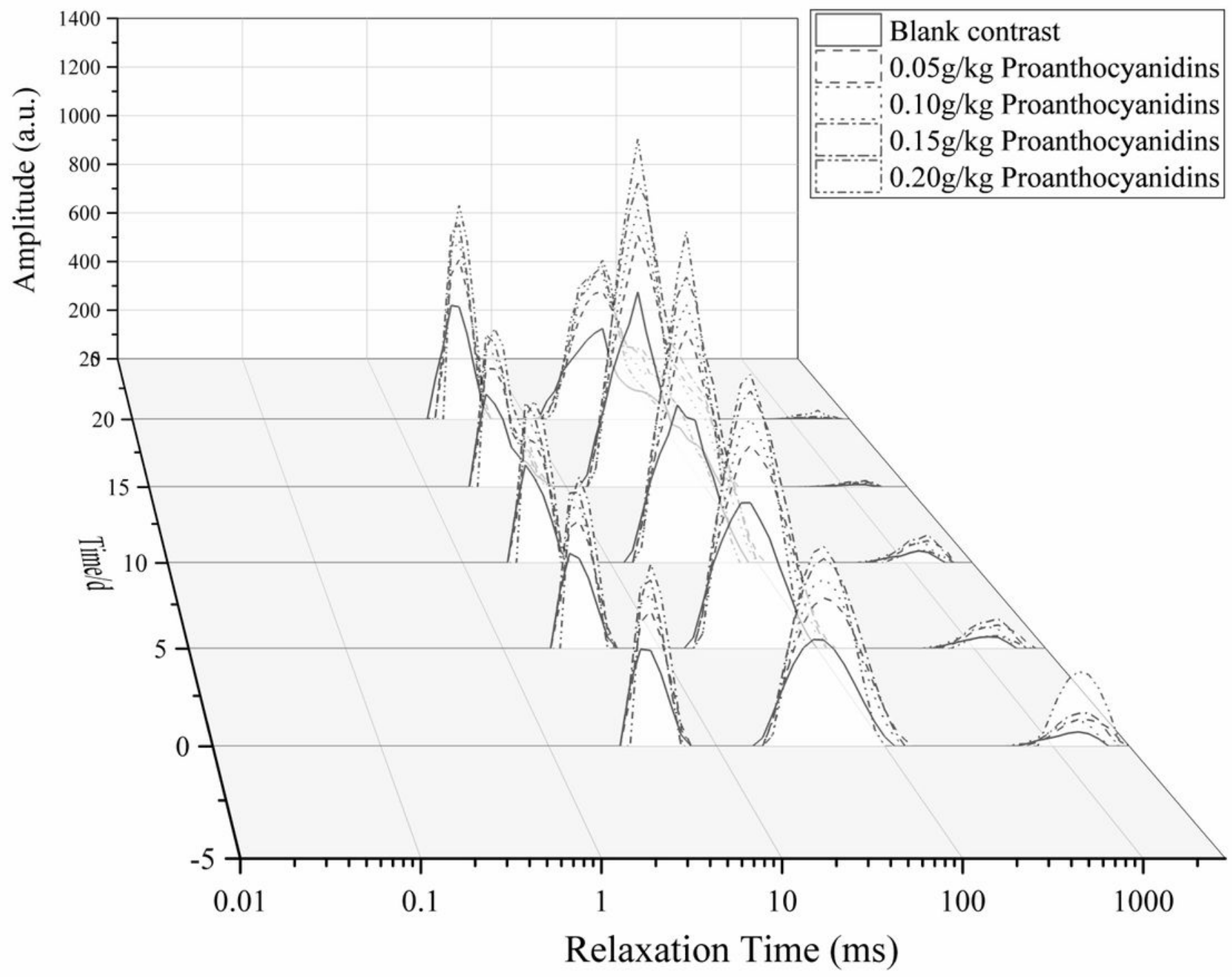

Figure 7

Overview 


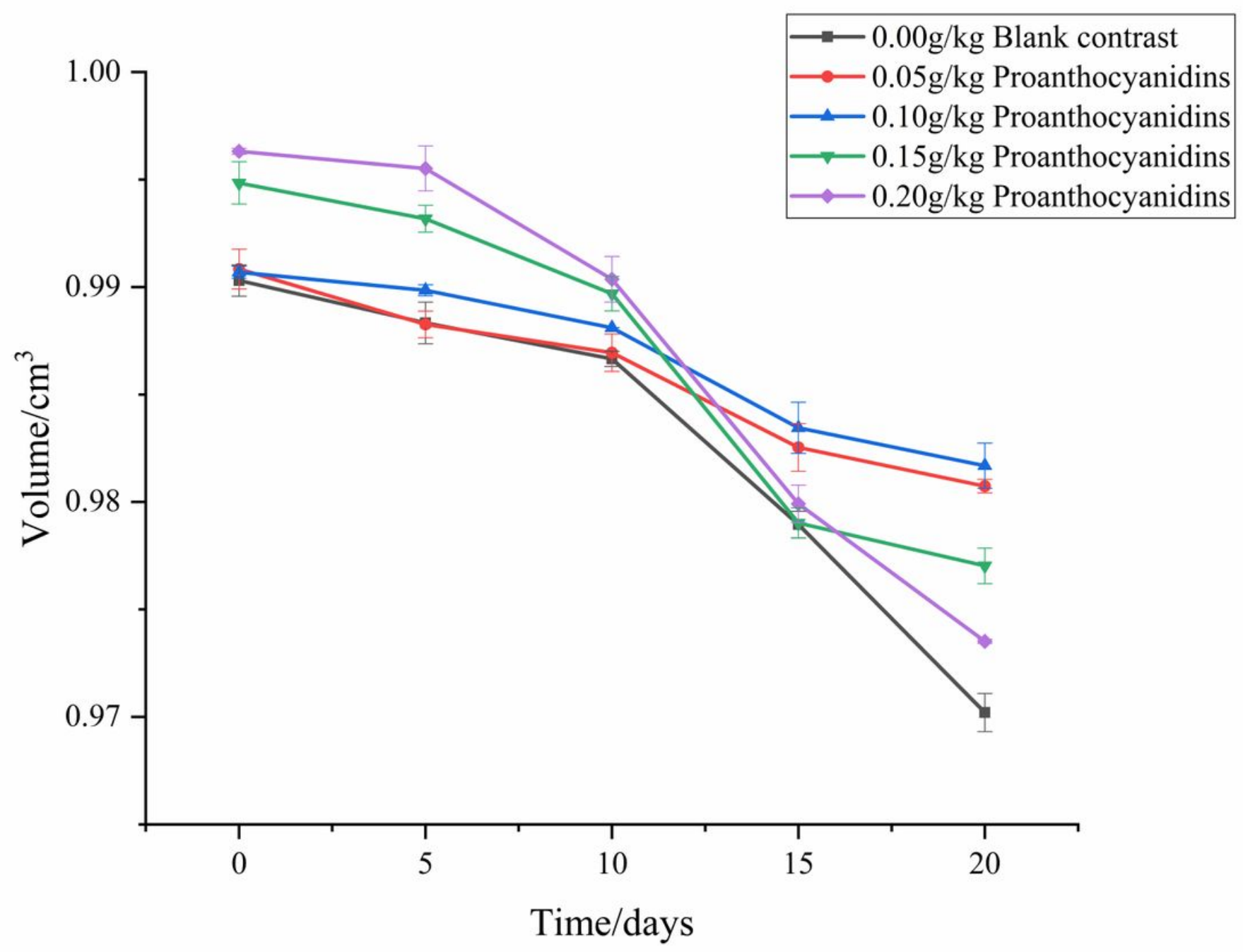

Figure 8

SPRS 


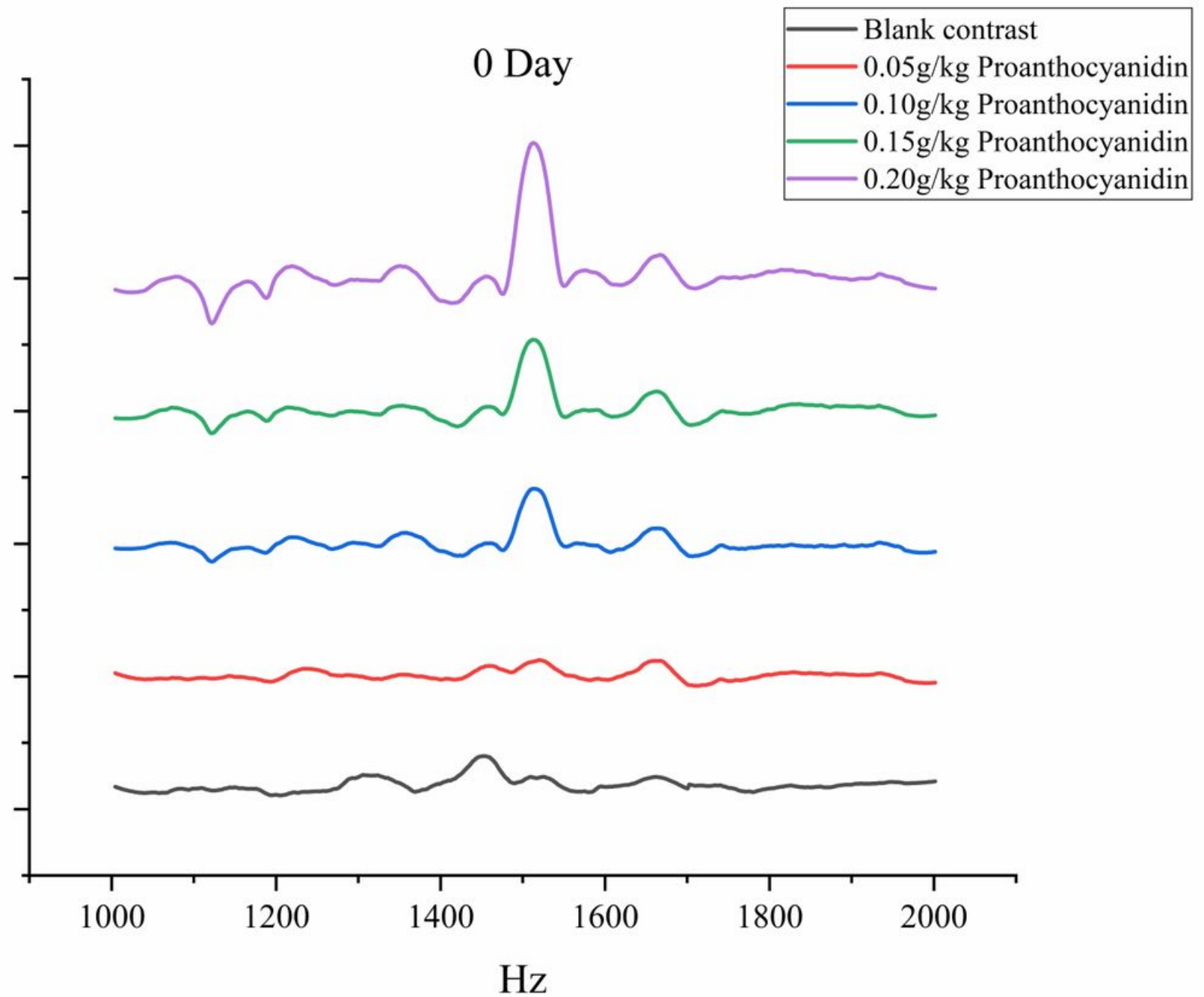

Figure 9

Raman spectroscopy $1000-2000 \mathrm{~cm}^{-1}$ 


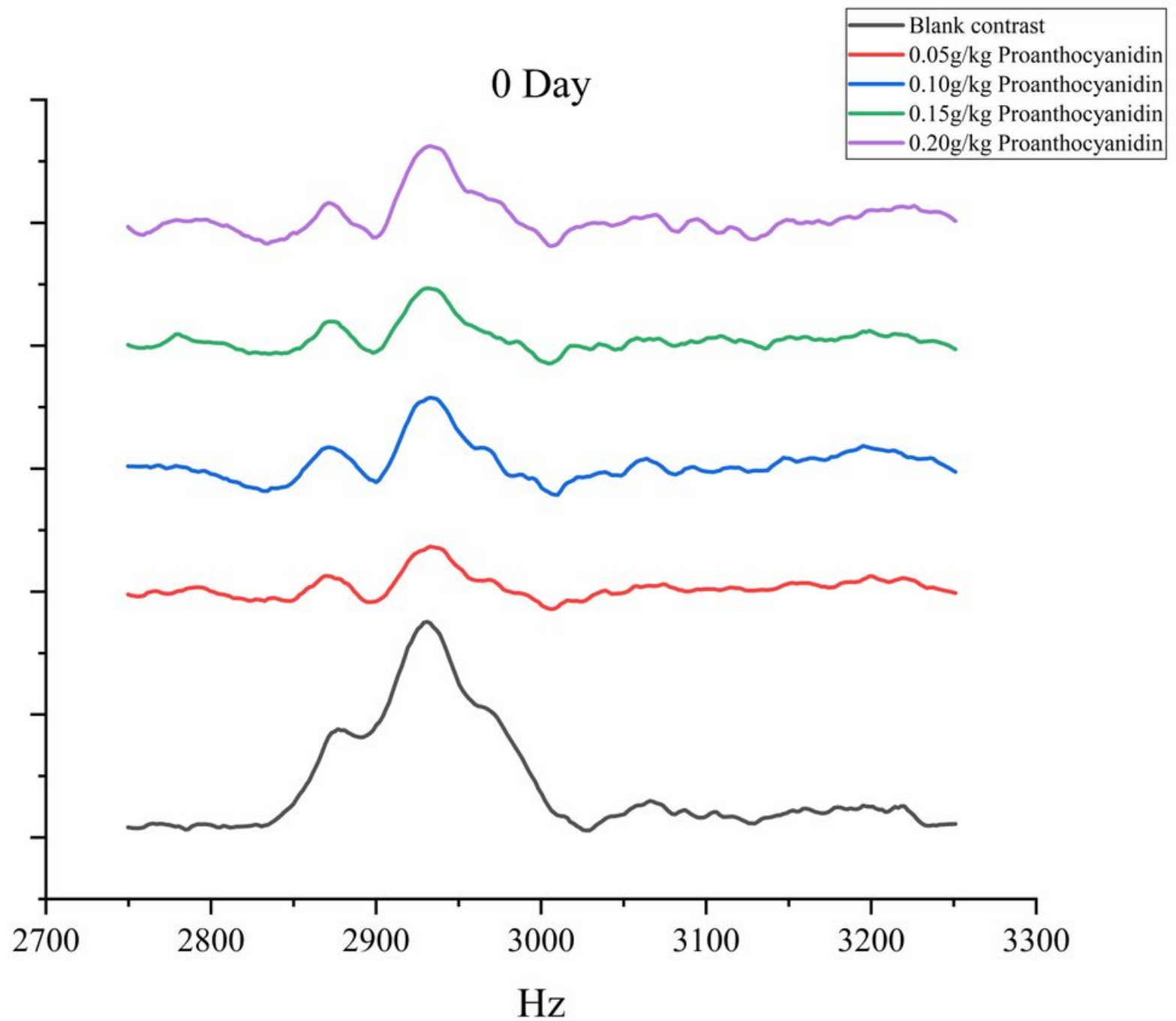

Figure 10

Raman spectroscopy $2750-3250 \mathrm{~cm}^{-1}$ 


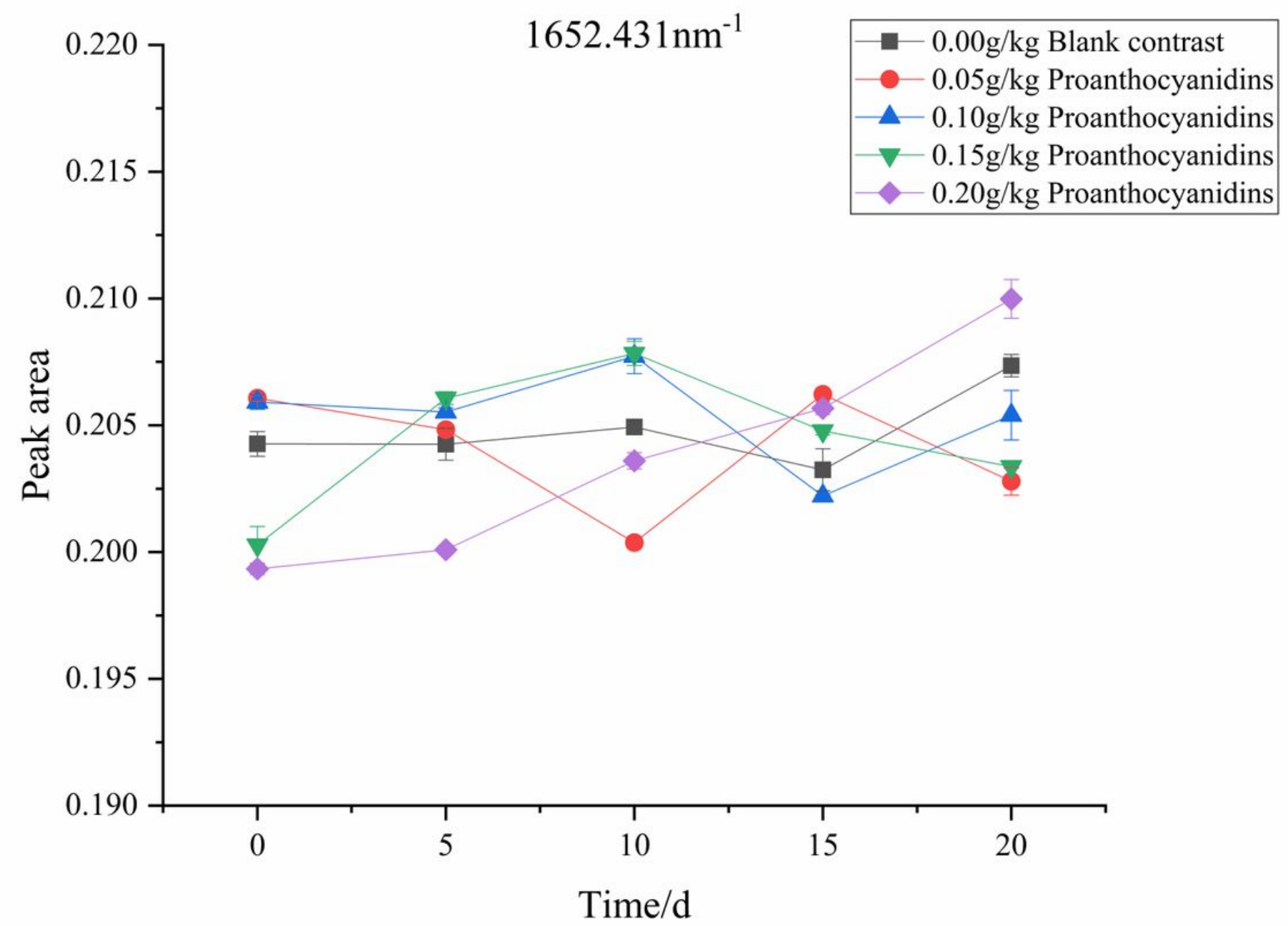

Figure 11

Overview of $1652.431 \mathrm{~cm}^{-1}$ in Raman spectroscopy 


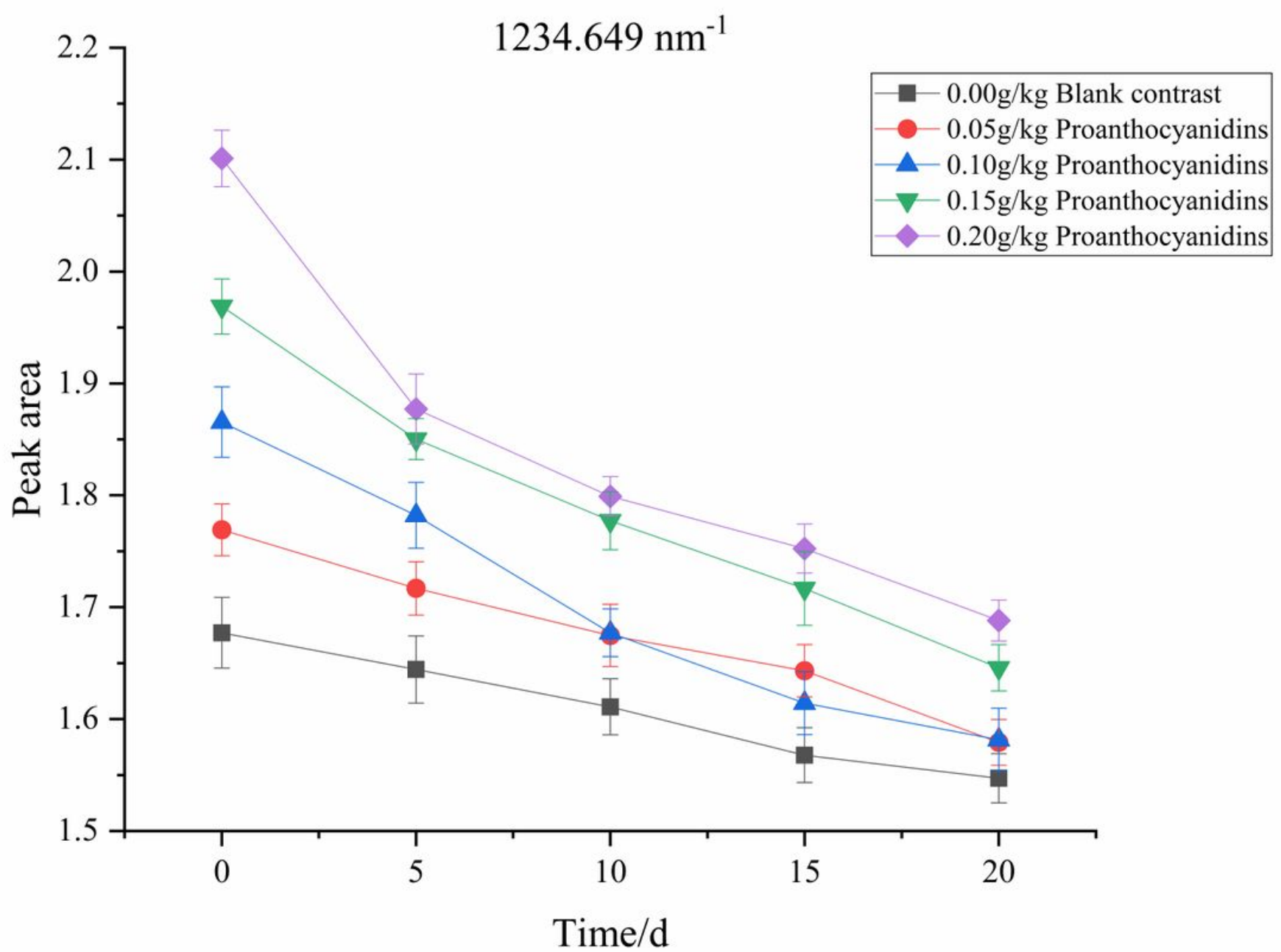

Figure 12

Overview of $1234.649 \mathrm{~cm}^{-1}$ in Raman spectroscopy 


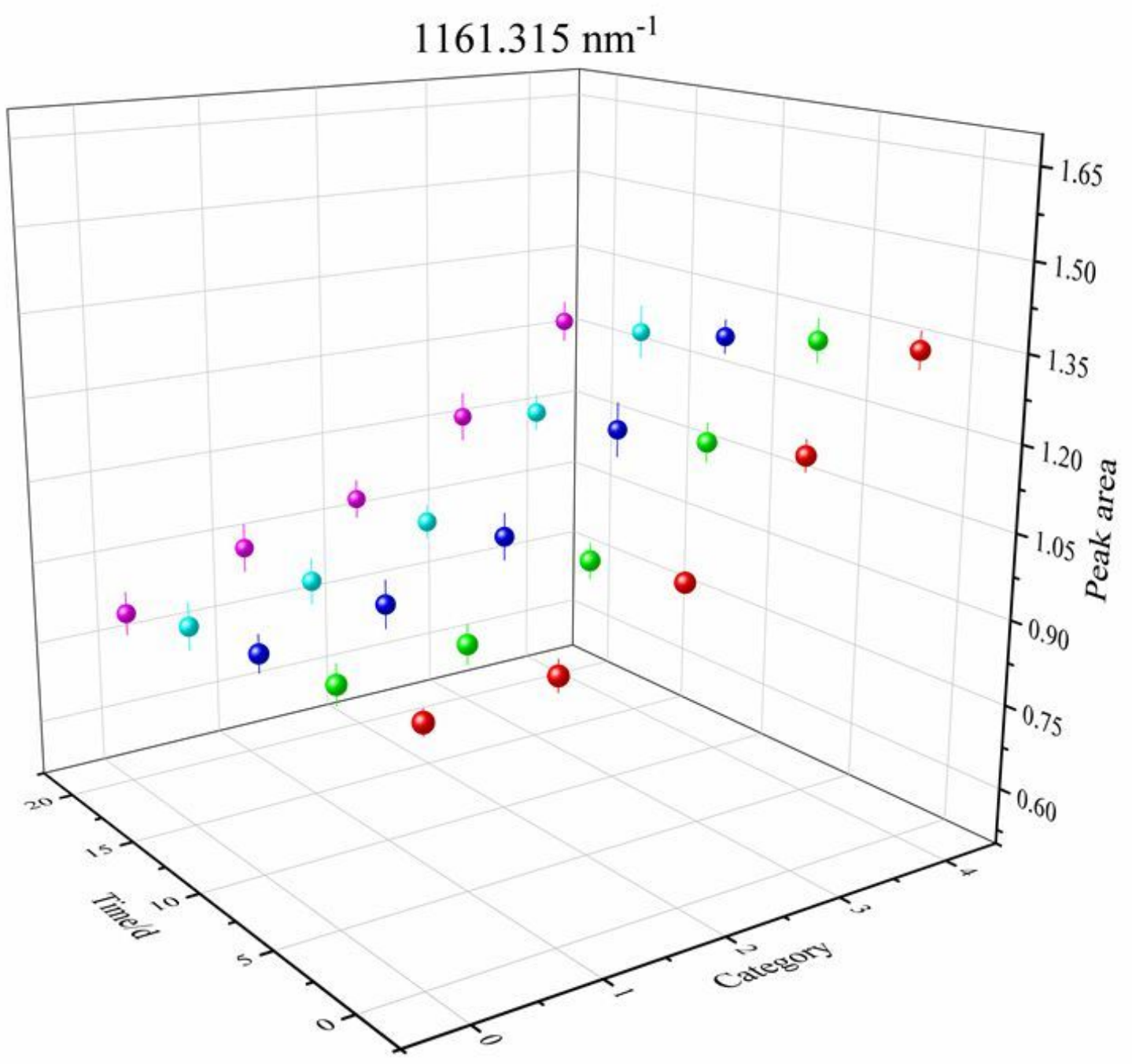

Figure 13

Overview of $1161.315 \mathrm{~cm}^{-1}$ in Raman spectroscopy

Figure 14

Overview of $1532.837 \mathrm{~cm}^{-1}$ in Raman spectroscopy

Figure 15

Overview of $1673.892 \mathrm{~cm}^{-1}$ in Raman spectroscopy 
Figure 16

-A, -B was Rheological properties of gel changes with temperature, -C, -D was Rheological properties of gel changes with temperature frequency

\section{Figure 17}

$-F$ was $G^{\prime} / G^{\prime \prime}$, -E was the complex viscosity, $-G$ was storage modulus and loss modulus of gel changes with temperature, $-\mathrm{H}$ was storage modulus and loss modulus of gel changes with frequency

$\mathrm{NaNO}_{2}$ Springiness

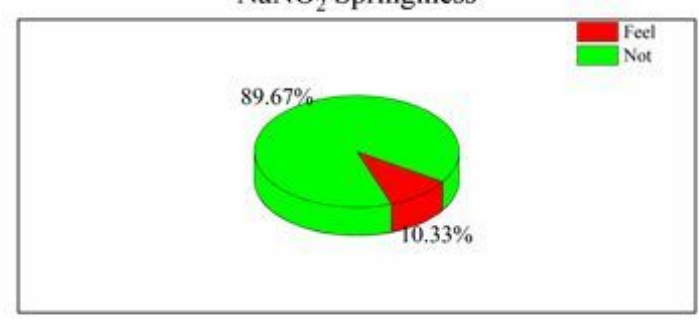

$\mathrm{NaNO}_{2}$ Chewiness

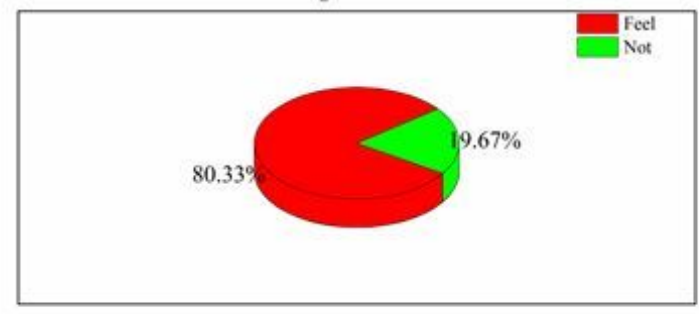

$\mathrm{NaNO}_{2}$ Hardness

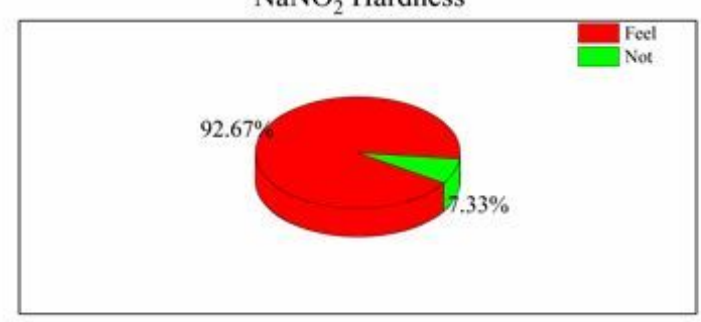

Proanthocyanidin Springiness

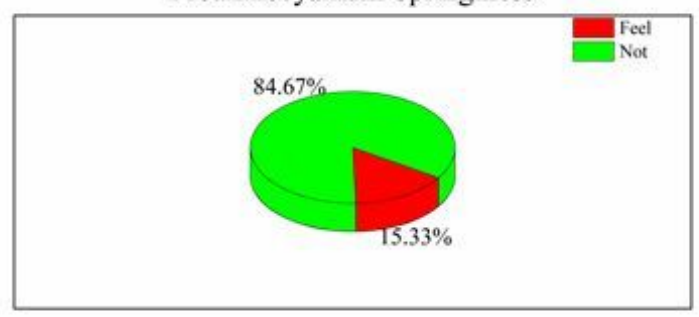

Proanthocyanidin Chewiness

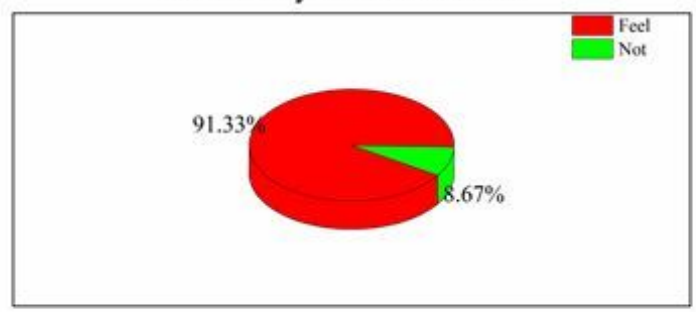

Proanthocyanidin Hardness

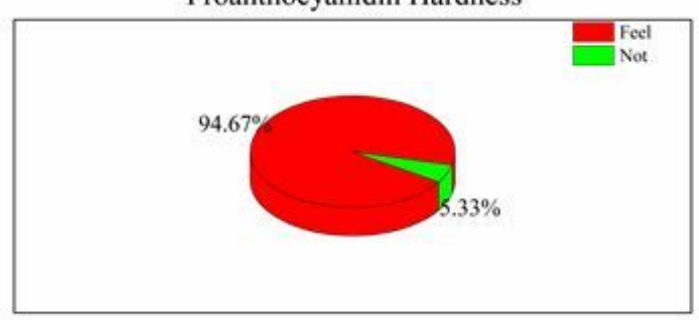

\section{Figure 18}

Questionnaire 
Figure 19

Microstructure picture

Figure 20

Gel object pictures 